\title{
Nitrification and inorganic nitrogen distribution in a large perturbed river/estuarine system: the Pearl River Estuary, China
}

\author{
M. Dai, L. Wang, X. Guo, W. Zhai, Q. Li, B. He, and S.-J. Kao \\ State Key Laboratory of Marine Environmental Science, Xiamen University, Xiamen 361005, China \\ Received: 31 January 2008 - Published in Biogeosciences Discuss.: 11 April 2008 \\ Revised: 18 July 2008 - Accepted: 25 July 2008 - Published: 3 September 2008
}

\begin{abstract}
We investigated the spatial distribution and seasonal variation of dissolved inorganic nitrogen in a large perturbed estuary, the Pearl River Estuary, based on three cruises conducted in winter (January 2005), summer (August 2005) and spring (March 2006). On-site incubation was also carried out for determining ammonium and nitrite oxidation rates (nitrification rates). We observed a year-round pattern of dramatic decrease in $\mathrm{NH}_{4}^{+}$, increase in $\mathrm{NO}_{3}^{-}$, but insignificant change in $\mathrm{NO}_{2}^{-}$in the upper estuary at salinity $\sim 0-5$. However, species and concentrations of inorganic nitrogen at upper estuary significantly changed with season. In winter, with low runoff, the most upper reach of the Pearl River Estuary showed relatively low rates of ammonia oxidation $\left(0-5.4 \mu \mathrm{mol} \mathrm{N} \mathrm{L} \mathrm{L}^{-1} \mathrm{~d}^{-1}\right)$ and nitrite oxidation $\left(0-5.2 \mu \mathrm{mol} \mathrm{N} \mathrm{L}{ }^{-1} \mathrm{~d}^{-1}\right)$, accompanied by extremely high concentrations of ammonia (up to $>800 \mu \mathrm{mol} \mathrm{L}^{-1}$ ) and nitrate (up to $>300 \mu \mathrm{mol} \mathrm{L}^{-1}$ ). In summer, the upper estuary showed higher nitrification rates (ammonia oxidation rate $\sim 1.5-33.1 \mu \mathrm{mol} \mathrm{N} \mathrm{L}^{-1} \mathrm{~d}^{-1}$, nitrite oxidation rate $\sim 0.6-$ $\left.32.0 \mu \mathrm{mol} \mathrm{N} \mathrm{L} \mathrm{L}^{-1} \mathrm{~d}^{-1}\right)$ with lower concentrations of ammonia $\left(<350 \mu \mathrm{mol} \mathrm{L}^{-1}\right)$ and nitrate $\left(<120 \mu \mathrm{mol} \mathrm{L}^{-1}\right)$. The Most Probable Number test showed relatively lower nitrifier abundance in summer at most sampling stations, indicating a greater specific nitrification rate per cell in the warm season. Temperature appeared to control nitrification rates to a large degree in different seasons. Spatial variability of nitrification rates appeared to be controlled by a combination of many other factors such as nutrient concentrations, nitrifier abundance and dissolved oxygen (DO) concentrations. In addition to aerobic respiration, nitrification contributed significantly to the consumption of DO and production of free $\mathrm{CO}_{2}$ at upper estuary. Nitrification-induced consumption accounted for up to approximately one third of the total wa-
\end{abstract}

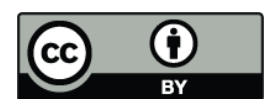

Correspondence to: M. Dai (mdai@xmu.edu.cn) ter column community DO consumption in the upper estuary during the surveyed periods, boosting environmental stress on this large estuarine ecosystem.

\section{Introduction}

Rivers play a crucial role in the delivery of nutrients to the ocean, making coastal waters particularly prone to eutrophication, which may cause harmful algal blooms and/or hypoxia, disrupting coastal ecosystems (e.g. Galloway et al., 2004; Howarth and Marino, 2006; Rabalais et al., 2002; Smith et al., 2006). Major research efforts have thus been devoted to the environmental consequence of the progressive increase in nutrient discharges associated with human activities, such as untreated domestic and industrial wastewaters, into estuarine and coastal environments (e.g. Gunnarsson et al., 2000; Howarth et al., 1996; National Research Council, 2000; Verity et al., 2006).

Among the various nutrients, nitrogen has received particular attention because of the magnitude of the associated environmental concerns and the complexity of nitrogen cycling after discharge into the aquatic environment (Galloway et al., 2004; Howarth and Marino, 2006). It is now recognized that oxidation of ammonium plays a pivotal role in generating a source of nitrate for denitrifying bacteria. The coupling of this obligately aerobic process (nitrification) with an anaerobic process (denitrification) leads to the loss of nitrogen to the atmosphere. Therefore, nitrification is crucial to an understanding of the nitrogen cycle in aquatic systems, particularly, the river/estuarine systems (Bianchi et al., 1997; Lomas and Lipschultz, 2006).

There have been many examples showing intensive nitrification in polluted rivers/estuaries that directly or indirectly (through organic nitrogen mineralization) receive large amounts of ammonium favorable to the development of nitrification (e.g. de Wilde and de Bie, 2000; Garnier et al., 2006;

Published by Copernicus Publications on behalf of the European Geosciences Union. 

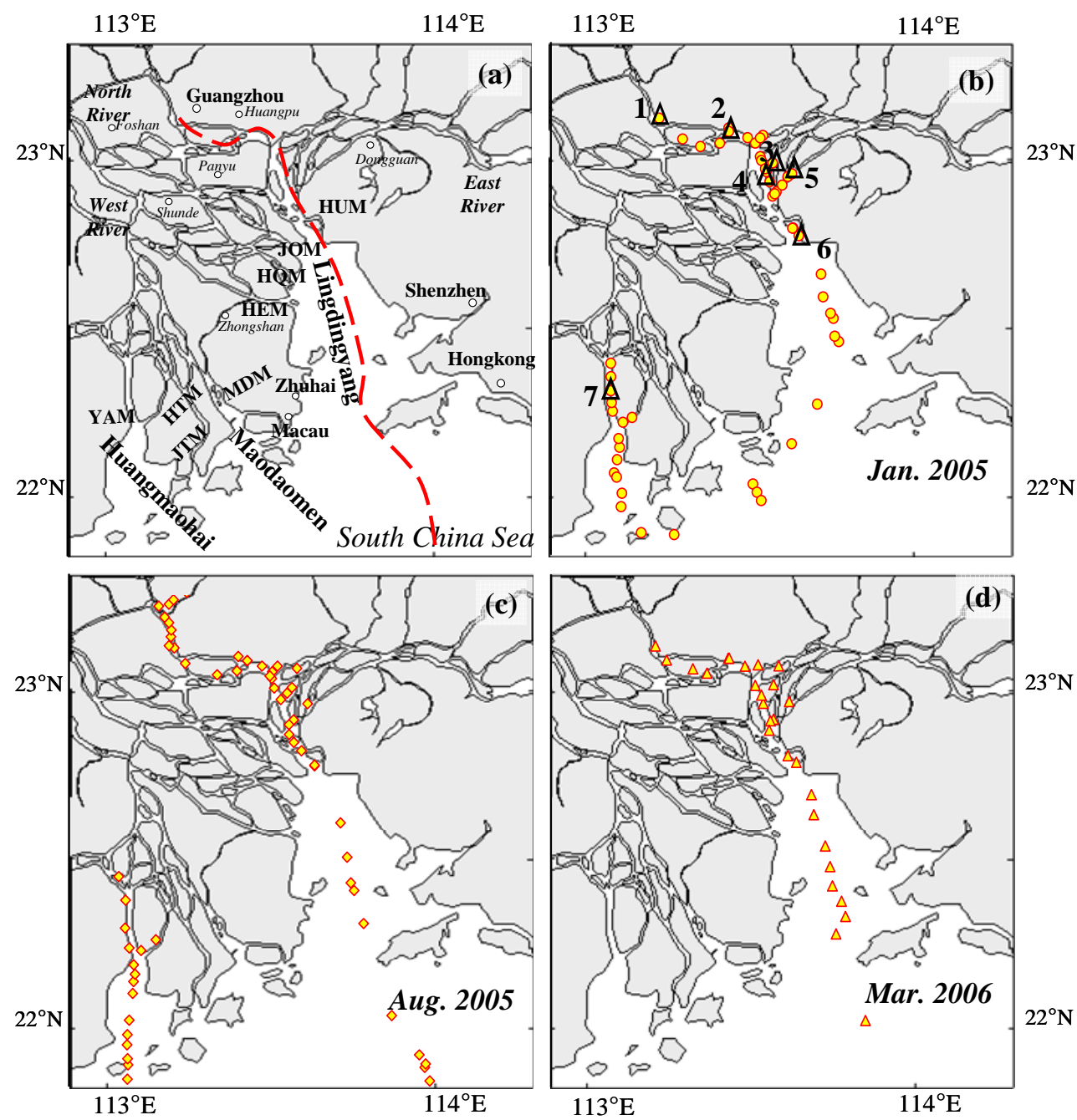

Fig. 1. Map of the Pearl River Estuary (a) and sampling sites (b, c, d) in different cruises. HUM, JOM, HQM and HEM designate Humen, Jiaomen, Hongqimen, and Hengmen, respectively, which are the eastern four outlets of the Pearl River Estuary. YAM and MDM designate, respectively, the Yamen and Maodaomen outlets. The three sub-estuaries, Lindingyang, Maodaomen and Huangmaohai, are also indicated. The red dashed line in panel (a) shows the main cruise track of the cruises. Nutrient sampling sites for January 2005, August 2005 and March 2006 cruises are in yellow symbols in panels (b), (c) and (d), respectively. Open triangles in panel (b) mark those stations for incubation.

Magalhaes et al., 2005; Xu et al., 2005). Transformation of nitrogen species from ammonia and nitrite to nitrate in river/estuaries during transportation not only modulates their relative distributions but also enhances oxygen consumption (e.g. Bianchi et al., 1997; Brion et al., 2000; Lipschultz et al., 1986). However, the inter-relationship between environmental conditions and nitrification in aquatic environments remains unclear (Strauss and Lamberti, 2000) and only a few reports, which are mainly limited to the seasonal variation of nitrification rates, include any attempt to elucidate factors regulating estuarine/coastal nitrification (Berounsky and Nixon, 1990; de Bie et al., 2002; Huesemann et al., 2002; Xia et al., 2004).

The Pearl River (Zhujiang) Estuary is one of the most complex estuarine systems in the world. The Pearl River dis- charges to the South China Sea through three sub-estuaries, the Lingdingyang, Maodaomen and Huangmaohai (Fig. 1a), via eight main outlets, or distributaries. This estuary is located in what has been one of the most rapidly developing areas of the world during the past two decades. The massive economic growth and urban development in this region has led to excessive release of wastes into the estuarine region (Tang, 1997). As a consequence, many environmental issues have emerged, such as ammonium contamination and hypoxia (Dai et al., 2006; Zhai et al., 2005), which at the same time offer an opportunity to examine nitrogen transformation in human-perturbed estuaries. Unfortunately, available data on the spatial and temporal variations of dissolved inorganic nitrogen are still limited in the open literature though research devoted to this region has grown recently in response 
Table 1. Basic hydrography of major sub-estuaries of the Pearl River.

\begin{tabular}{|c|c|c|c|c|c|c|}
\hline Sub-estuary & Outlet & $\begin{array}{l}\text { Area } \\
\left(\mathrm{km}^{2}\right)\end{array}$ & $\begin{array}{l}\text { Volume } \\
\left(10^{6} \mathrm{~m}^{3}\right)\end{array}$ & $\begin{array}{c}\text { Water }^{\mathrm{b}} \\
\text { discharge }(\%)\end{array}$ & $\begin{array}{c}\text { Sediment }^{\mathrm{c}} \\
\operatorname{load}(\%)\end{array}$ & $\begin{array}{c}\text { Tidal }^{\mathrm{d}} \\
\text { exchange }(\%)\end{array}$ \\
\hline Lingdingyang & $\begin{array}{l}\text { Humen (HUM) } \\
\text { Jiaomen (JOM) } \\
\text { Hongqimen (HQM) } \\
\text { Hengmen (HEM) }\end{array}$ & 1180 & 8068 & 55 & 46 & $\sim 60$ \\
\hline Modaomen & $\begin{array}{l}\text { Modaomen (MDM) } \\
\text { Jitimen (JTM) }\end{array}$ & 350 & 1750 & 28 & 33 & \\
\hline Huangmaohai & $\begin{array}{l}\text { Hutiaomen (HTM) } \\
\text { Yamen (YAM) }\end{array}$ & 440 & 1760 & 13 & 11 & $\sim 28$ \\
\hline
\end{tabular}

${ }^{a}$ Wong and Cheung (2000)

b Cheung et al. (2000)

c PRWRC/PRRCC (1991)

d Cheng (2001)

to progressively worsening environmental conditions (Cai et al., 2004; Yin, 2002; Yin et al., 2001; Zhang et al., 1999). Moreover, most of the previous studies have focused on the Lingdingyang Estuary (one of the three sub-estuary complexes) leaving information on nutrient biogeochemistry in the other two sub-estuaries unavailable.

Based upon the distribution of inorganic nitrogen species and the stoichiometry of dissolved oxygen (DO) consumption and free $\mathrm{CO}_{2}$ production, we inferred that strong nitrification should occur in the water column in the upper reaches of the Pearl River Estuary (Dai et al., 2006). However, rates and controlling factors of nitrification have not been addressed. In this study, we conducted temporal and spatial investigations on dissolved inorganic nitrogen and nitrification rates with a special attention being given to their interrelationship with environmental conditions.

\section{Materials and methods}

\subsection{Study area}

The Pearl River is the second largest river in China next to the Yangtze River (Changjiang) in terms of freshwater discharge. The Pearl River has three main tributaries (Fig. 1a), namely the Xijiang (West River), Beijiang (North River) and Dongjiang (East River). The annual mean river discharge of the Pearl River is $3.26 \times 10^{11} \mathrm{~m}^{3} \mathrm{yr}^{-1}$, of which $80 \%$ occurs in the wet season from April to September (Zhao, 1990). The water discharge rate shows significant seasonality. During the dry winter, monthly average flow rate is around $2000 \mathrm{~m}^{3} \mathrm{~s}^{-1}$, while, in the wet summer, monthly average water flow rate can be 8 times higher, reaching $16000 \mathrm{~m}^{3} \mathrm{~s}^{-1}$ in July.

The Pearl River Delta is formed by two funnel-shaped bays, the Lingdingyang and the Huangmaohai (Fig. 1a). The
Lingdingyang, which is conventionally regarded as the Pearl River Estuary, is the largest sub-estuary with an area of $1180 \mathrm{~km}^{2}$ and collects about $55 \%$ of the runoff and $46 \%$ of the suspended sediment load (see Table 1) of the entire Pearl River system (Zhao, 1990). The Lingdingyang is surrounded by a number of metropolises such as Guangzhou, Shenzhen, Macao and Hong Kong. The Huangmaohai has a surface area of $440 \mathrm{~km}^{2}$ with an annual mean freshwater input of $4.05 \times 10^{10} \mathrm{~m}^{3} \mathrm{yr}^{-1}$, accounting for $13 \%$ of the total river discharge (Zhao, 1990). The Huangmaohai is surrounded by rapidly developing cities such as Xinhui and Jiangmen (not shown in Fig. 1). Between the two bays is an arc like siltation zone with its apex at Modaomen. The Modaomen subestuary receives $28 \%$ of the total freshwater input. Eight outlets are distributed within this delta-estuary system. Four of the eight, the Humen, Jiaomen, Hongqimen and Hengmen, drain water runoff from the East River, the North River and several branches of the West River into the Lingdingyang, which is a microtidal estuary with an average tidal range of 0.8-1.9 m increasing towards the Humen. The West River mainly discharges into the Modaomen sub-estuary via the Modaomen and Jitimen outlets. The Yamen and Hutiaomen deliver water runoff from two branches of the West River and a small local river (the Tanjiang River, not shown) to the Huangmaohai sub-estuary, which is a macrotidal sub-estuary (Wu and Shen, 1999).

The water residence time in summer is shorter than in winter in all three sub-estuaries. The Lingdingyang has the shortest residence time (faster exchange) among the three subestuaries in both wet and dry seasons (Cheung et al., 2000). The estuarine water is usually stratified during the summer wet season and well mixed during the winter dry season. The salt wedge and turbidity maximum migrate seasonally due to changes in freshwater runoff (Mao et al., 2004). In the wet seasons, the freshwater effect covers the entire Lingdingyang 
resulting in a salinity of $<20-25$ in the surface water; while in dry seasons, seawater may occupy the whole estuary with a salt wedge, even reaching Guangzhou (Tian, 1994).

To obtain a more comprehensive view of the Pearl River Estuary, this study focused on not only the Lingdingyang sub-estuary but also the Huangmaohai and off-estuary zones. To make the discussion more convenient, we divided the Lingdingyang sub-estuary into three parts based on the relative distance to the Humen Outlet, namely, Guangzhou upstream $(-100$ to $-30 \mathrm{~km})$, Guangzhou downstream $(-30$ to $0 \mathrm{~km})$ and Humen downstream $(>0 \mathrm{~km})$ (see Fig. 4). Similarly, the Yamen is used as a reference point for the transect in the Huangmaohai.

\subsection{Sampling}

Water samples were collected during three cruises undertaken in January 2005, August 2005 and March 2006, representing the cold and dry season with low water flow, the warm and flood season with high water flow and the transitional season with medium flow, respectively. The monthly average discharge was $2068 \mathrm{~m}^{3} \mathrm{~s}^{-1}$ in January 2005, $2705 \mathrm{~m}^{3} \mathrm{~s}^{-1}$ in March 2006 and $6414 \mathrm{~m}^{3} \mathrm{~s}^{-1}$ in August 2005. During our sampling cruises in January 2005 and March 2006, the monthly average discharge was slightly higher than the long-term average, while in August 2005 the monthly average discharge was 54\% lower than the longterm average discharge. The average surface temperature during these three cruises was $16^{\circ} \mathrm{C}, 19^{\circ} \mathrm{C}$ and $31^{\circ} \mathrm{C}$, respectively.

Samples were taken along a main transect as shown in Fig. 1 where stations are dotted (Fig. 1b-d). In January 2005 and August 2005, we expanded our sampling to the Huangmaohai sub-estuary. Discrete sampling was guided by the salinity gradient within the estuarine mixing zone and by distance when no salinity changes occurred at the upstream $\mathrm{Hu}$ men in the wet season. At selected stations, we took incubation samples to determine nitrification rates. These stations are numbered in Fig. 1b. It should be noted that Stations 1-2 and Station 4 are located in the main channel of the upstream Humen, and Stations 3 and 5 are located at the branches of the lower East River. Station 6 is located in the downstream Humen of the upper Lingdingyang sub-estuary and Station 7 is located upstream of the Yamen Outlet (Fig. 1).

Water column samples for nutrients, bacterial abundance, nitrifying bacteria and $\mathrm{pH}$ were collected using $2.5 \mathrm{~L}$ Go-Flo bottles. Surface samples for nitrifying bacteria were taken with a clean pumping system equipped with a FloJet ${ }^{\circledR}$ pump and Teflon lined tubing. Surface samples for nutrients were collected using the same system with the addition of on-line cartridge filters (pore size $\sim 1 \mu \mathrm{m}$ ), and were subsequently filtered with $0.45 \mu \mathrm{m}$ cellulose acetate membranes.

\subsection{Incubation experiments}

To determine nitrification rates, on-deck incubation was carried out in $4 \mathrm{~L}$ narrow neck amber glass bottles using an inhibitor technique, which has been widely used to measure nitrification rates in coastal marine environments (Bianchi et al., 1997; de Bie et al., 2002; Feray et al., 1999). Water samples were homogenized in a $20 \mathrm{~L}$ pre-cleaned polyethylene container, and then dispensed into the incubation bottles. One aliquot was incubated with the addition of allyithiourea (ATU, at $100 \mathrm{~m} \mathrm{~L}^{-1}$ ), which inhibits the oxidation of ammonia $\left(\mathrm{NH}_{3}\right)$ to nitrite $\left(\mathrm{NO}_{2}^{-}\right)$. Another aliquot was incubated with the addition of $\mathrm{NaClO}_{3}\left(10 \mathrm{mg} \mathrm{L}^{-1}\right)$ to inhibit oxidation of $\mathrm{NO}_{2}^{-}$to nitrate $\left(\mathrm{NO}_{3}^{-}\right)$. A third aliquot acted as a control, without adding any inhibitors. The concentrations of both inhibitors were optimized based on a set of pre-experiments both in the laboratory and on site (data not shown). The experiments were carried out on deck with through running water to maintain the in situ water temperature. Sub-samples were taken out at $4-8 \mathrm{~h}$ intervals for analyzing nutrients. Nitrification rates were estimated from the evolution of nutrient concentrations in incubation bottles during the exponential phase of increase or decrease in $\mathrm{NO}_{2}^{-}$ (Bianchi et al., 1992). Bulk oxygen consumption rates were determined as previously described in Dai et al. (2006).

\subsection{Analyses}

\subsubsection{Nutrients}

Nutrient samples were stored at $-20^{\circ} \mathrm{C}$ until analysis except for $\mathrm{NH}_{4}^{+}$, which was analyzed on deck with the indophenol blue spectrophotometric method (Pai et al., 2001). $\mathrm{NO}_{2}^{-}$and $\mathrm{NO}_{3}^{-}$measurements were run in our land-based laboratory at Xiamen University according to classical colorimetric methods with a Technicon AA3 Auto-Analyzer (Bran-Lube). The detection limits for $\mathrm{NO}_{2}^{-}, \mathrm{NO}_{3}^{-}$and $\mathrm{NH}_{4}^{+}$were $0.02,0.07$ and $0.16 \mu \mathrm{mol} \mathrm{L}^{-1}$, respectively.

\subsubsection{Abundance of nitrifying bacteria}

The abundance of nitrifying bacteria (nitrifiers) was determined using the most probable number (MPN)-Griess technique (Abril et al., 2000; Man, 1975; Pauer and Auer, 2000). Prior to incubation, all the tubes, the culture media, and the $\mathrm{NaCl}$ solution $(0.9 \%$, for dilution) were sterilized in an autoclave at $120^{\circ} \mathrm{C}$ for $20 \mathrm{~min}$. The media that we used were identical to those used by Chen and Zheng (1985), in which $2.0 \mathrm{~g}$ of $\left(\mathrm{NH}_{4}\right)_{2} \mathrm{SO}_{4}, 1 \mathrm{~g}$ of $\mathrm{K}_{2} \mathrm{HPO}_{4}, 0.5 \mathrm{~g}$ of $\mathrm{MgSO}_{4}, 2 \mathrm{~g}$ of $\mathrm{NaCl}, 0.4 \mathrm{~g}$ of $\mathrm{FeSO}_{4}$ and $5 \mathrm{~g}$ of $\mathrm{CaCO}_{3}$ were dissolved in $1 \mathrm{~L}$ of distilled water. The $\mathrm{pH}$ of the media solution was adjusted to 7.2. Samples were diluted to a different degree (from $10^{-1}$ to $10^{-7}$ ) using sterilized $\mathrm{NaCl}$ solution. One $\mathrm{mL}$ of inoculum with a different degree of dilution was then added to a series of four tubes containing $9 \mathrm{~mL}$ of the culture 
media. These tubes were then incubated for 45-60 days at $28 \pm 2^{\circ} \mathrm{C}$ in the dark. Finally, Griess reagent and diphenylamine were applied to examine whether nitrite or nitrate was formed. The abundance of nitrifiers was estimated based on classical MPN statistics (Man, 1975).

This MPN-Griess technique has been widely used and it is capable of diagnosing the existence of nitrifiers and estimating bacterial densities (e.g. Diab et al., 1993; Koops and Pommerening-Roser, 2001; Pauer and Auer, 2000). It should be noted that the MPN-Griess method has been criticized for its potential underestimation of bacterial populations (Belser, 1979). When compared with the immunofluorescence technique or MPN-PCR method, it is considered to lead to an insignificant underestimation of cell counts (Feray et al., 1999; Malhautier et al., 1998). However, the MPN-Griess technique is still considered to be advantageous for enumerating the autographic nitrifying community because many defects may exist in other methods (Feray et al., 1999; Konuma et al., 2001). We have conducted a series of laboratory experiments using model nitrifiers and the results revealed a good consistency of cell abundances in duplicate samples. Standard deviations between replicates were $30 \%, 38 \%$ and $21 \%$ for cell ranges of $<50$ cell $\mathrm{mL}^{-1},>100$ cell $\mathrm{mL}^{-1}$, and $>1000$ cell $\mathrm{mL}^{-1}$, respectively. Replicates were also taken for field samples in March 2006. Results showed that the standard deviation for field samples was better than $40 \%$.

\subsubsection{Temperature, salinity, $\mathrm{DO}$ and $\mathrm{pH}$}

Temperature and salinity were measured continuously using a YSI 6600 multi-parameter meter fitted in the underway measurement system described in Zhai et al. (2005) and Dai et al. (2006). Discrete DO was measured on board using the Winkler method. $\mathrm{pH}$ was measured on board within $4 \mathrm{~h}$ of sampling with a Corning ${ }^{\circledR} 350 \mathrm{pH} /$ ions analyzer and Orion Ross combination $\mathrm{pH}$ electrode calibrated against 3 NIST traceable buffers.

\section{Results}

3.1 Spatial-temporal distribution of inorganic nutrients and DO

Table 2 summarizes the data of hydrochemical parameters collected in this study and reported in the literature at (or near) the freshwater endmembers (the Humen and Yamen outlets) of the Pearl River. All the data listed in Table 2 (except that in January 2005 at the upstream Yamen) were measured under a salinity $<5$. Wide concentration ranges at the freshwater endmembers were noticeable for all nutrients and DO in the study area (Figs. 3 and 4). The highly variable endmember concentrations were apparently influenced by the seasonal variation of river discharge, which had profound effects on the supply of organics and nutrients as well as the water mixing of the estuary.

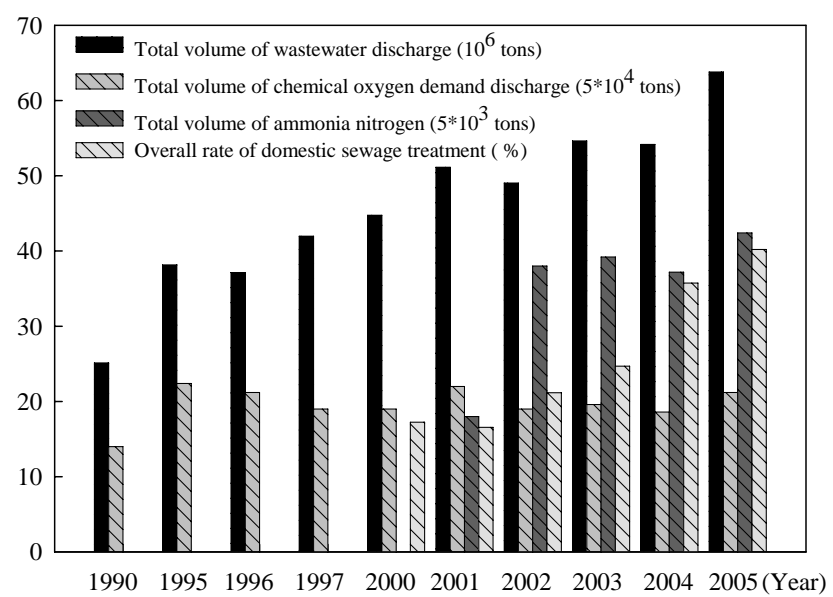

Fig. 2. Wastewater discharge from Guangdong Province, China between 1990 and 2005. Data between 1990 and 1997 are from Ho and Hui (2001), while the rest of the data are based on Environmental Status Bulletins of Guangdong Province, China (http: //www.gdepb.gov.cn)

The maximum $\mathrm{NO}_{3}^{-}$concentrations observed in this study were $190 \mu \mathrm{mol} \mathrm{L}^{-1}$ in January $2005,260 \mu \mathrm{mol} \mathrm{L}^{-1}$ in March 2006 and $110 \mu \mathrm{mol} \mathrm{L}^{-1}$ in August 2005. $\mathrm{PO}_{4}^{3-}$ was overall at a level of $1 \mu \mathrm{mol} \mathrm{L}^{-1}$ with the maximum concentration $\left(5.6 \mu \mathrm{mol} \mathrm{L}^{-1}\right)$ observed in August 2005 at the upstream Humen. These very high $\mathrm{NO}_{3}^{-}$and considerably low $\mathrm{PO}_{4}^{3-}$ concentrations are characteristic of the Pearl River as compared to other world major rivers (Cai et al., 2004; Yin et al., 2001; Zhang et al., 1999). Observed N/P ratios (total dissolved inorganic nitrogen to phosphate) in the upper reaches of the Pearl River Estuary ranged from 470-510 in January 2005 to 300-470 in March 2006, and 70-230 in August 2005 , showing a significant seasonal variability with higher N/P ratios in the dry winter. This N/P ratio declined seaward (not shown), reaching $\sim 80-100$ in the vicinity of the Humen in both winter and summer, similar to what was previously documented (Cai et al., 2004; Dai et al., 2006; Zhang et al., 1999). Silicate ranged between 50 and $150 \mu \mathrm{mol} \mathrm{L}^{-1}$, which is comparable with historical data (Cai et al., 2004; Dai et al., 2006; Lin et al., 1985; Zhang et al., 1999).

For the upstream Humen, extremely high $\mathrm{NH}_{4}^{+}$concentration ( $>800 \mu \mathrm{mol} \mathrm{L}^{-1}$ ) was observed in January 2005, but it was lower $\left(\sim 560 \mu \mathrm{mol} \mathrm{L}^{-1}\right)$ in March 2006 and dropped to $\sim 340 \mu \mathrm{mol} \mathrm{L}^{-1}$ in August 2005. In comparison, $\mathrm{NH}_{4}^{+}$ at the Yamen was considerably lower, ranging from a few $\mu \mathrm{mol} \mathrm{L}{ }^{-1}$ in August 2005 to $<50 \mu \mathrm{mol} \mathrm{L}^{-1}$ in January 2005 , revealing a similar seasonal pattern. The decreasing tendency in $\mathrm{NH}_{4}^{+}$from dry to wet seasons was likely to be due to freshwater dilution. It must be pointed out that these high levels of $\mathrm{NH}_{4}^{+}$were observed in the upstream Humen, in the Guangzhou section (see Fig. 3) of the Pearl River, which has been directly impacted by regional waste discharge. This 
Table 2. Summary of nutrient $\left(\mu \mathrm{mol} \mathrm{L}^{-1}\right)$ and $\mathrm{DO}\left(\mathrm{mg} \mathrm{L}^{-1}\right)$ data in the literature and in this study at the low-salinity zone of the two sub-estuaries of the Pearl River: Lindingyang and Huangmaohai. DIN denotes the sum of $\mathrm{NO}_{2}^{-}, \mathrm{NH}_{4}^{+}$and $\mathrm{NO}_{3}^{-}$.

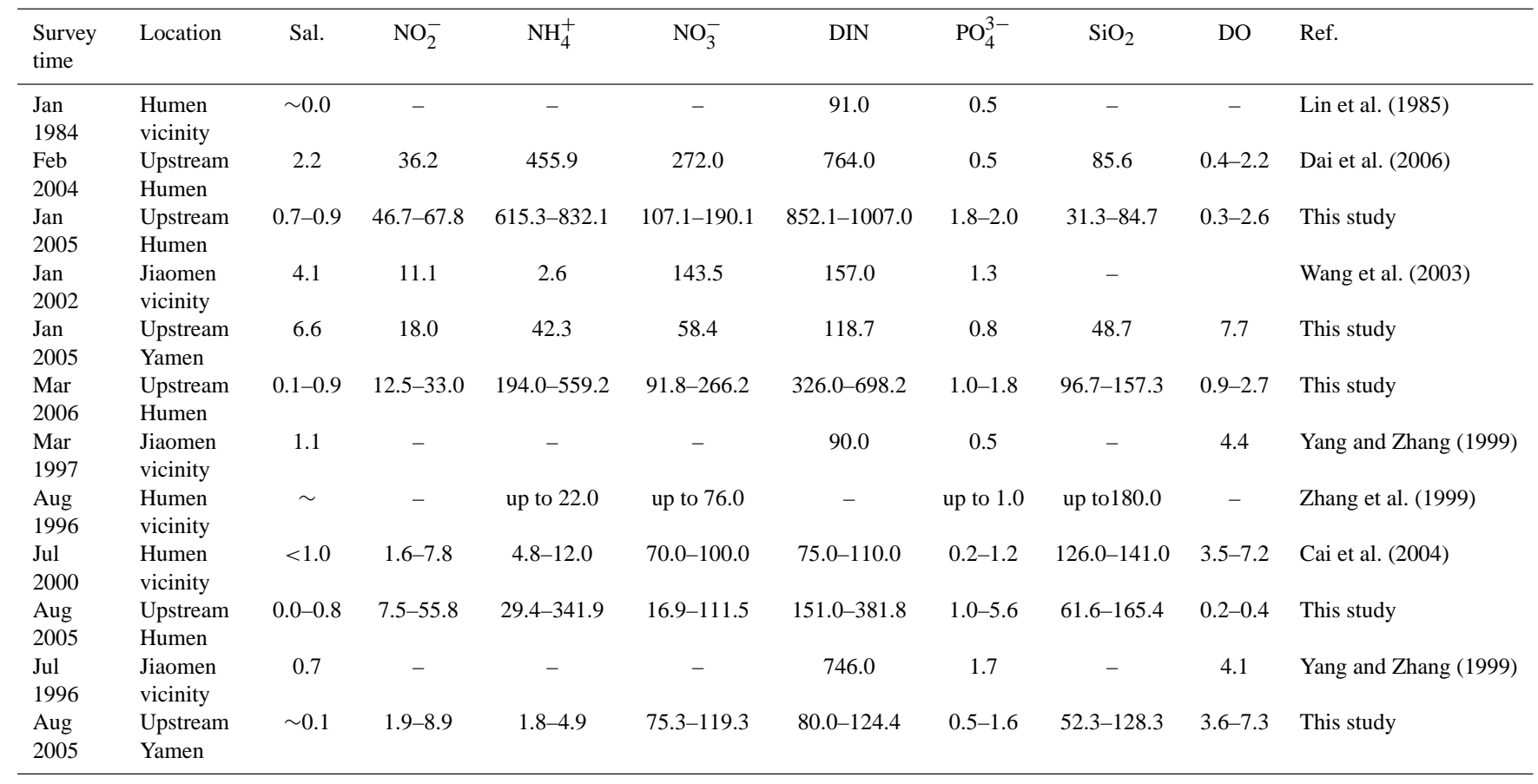

waste discharge has increased due to regional development that began $\sim 20$ years ago. This is manifested in Fig. 2 which clearly shows the increase in discharges of total wastewater, chemical oxygen demand, and ammoniacal nitrogen, which began to be intensified in the new century.

The spatial distribution of $\mathrm{NH}_{4}^{+}, \mathrm{NO}_{2}^{-}$and $\mathrm{NO}_{3}^{-}$and $\mathrm{DO}$ during different cruises are demonstrated, respectively, in Fig. 3b-e for the Lingdingyang and in Fig. $3 g-j$ for the Huangmaohai. Concentrations against salinity along the two transects are presented, respectively, in Fig. 4a-d and Fig. 4e-h. In the dry season (January 2005) with low freshwater input, surface salinity could be as high as 18 in the vicinity of the Humen Outlet (similar to February 2004 reported in Dai et al., 2006). By contrast, surface salinity was $<1$ at the same station even at high tide in August 2005 and $\sim 2$ in March 2006 (Fig. 3a). A similar salinity pattern was observed in the vicinity of the Yamen Outlet (Fig. 3f), which was $\sim 0$ and $\sim 13$ in August 2005 and January 2005, respectively. During low flow, seawater apparently intruded landward and this seawater intrusion supplied DO-rich seawater to the upstream area (Fig. $3 \mathrm{~b}$ and g).

Sampling in all cruises covered a full range of salinity from 0 to $>30$. Over such a wide range, sampling from the upstream Guangzhou to the downstream Humen (left panels in Fig. 3), covered total DIN ranges of $90-1000 \mu \mathrm{mol} \mathrm{L}^{-1}$, $40-700 \mu \mathrm{mol} \mathrm{L}^{-1}$ and $0-380 \mu \mathrm{mol} \mathrm{L}^{-1}$ in January 2005,
March 2006 and August 2005, respectively. Short water residence time and larger freshwater dilution may have accounted for this overall lower total DIN in August. Yet, a few peaks of $\mathrm{NH}_{4}^{+}, \mathrm{NO}_{2}^{-}$and $\mathrm{NO}_{3}^{-}$appeared at the upper reach above the Humen. Occurrence of those peaks was related to branch or local sewage inputs from major cities, and meanwhile, their locations may have been affected by the tidal motion superimposed by the complex geometry of the Lingdingyang (Fig. 3). Low-nutrient and DO-rich seawater mixing accounted for the significant seaward-increasing trend in DO and seaward-decreasing trend in all nitrogen species. High levels of inorganic nitrogen and similar distribution patterns are observed in the hypoxic area of the polluted Scheldt and the Seine estuaries (Abril and Frankignoulle, 2001; de Wilde and de Bie, 2000; Garnier et al., 2001).

In all seasons, $\mathrm{NH}_{4}^{+}$was the dominant species of inorganic nitrogen in the upper reach of the Lingdingyang sub-estuary. In both Figs. 3 and 4, we see that $\mathrm{NH}_{4}^{+}$dropped rapidly against salinity following the typical removal curve. This removal was associated with an increase in $\mathrm{NO}_{3}^{-}$concentration. The relative abundance of nitrate became important seaward, reaching a concentration equivalent to that of $\mathrm{NH}_{4}^{+}$ at a salinity $\sim 10$ (Fig. $4 \mathrm{~b}-\mathrm{d}$ ). The maximum $\mathrm{NO}_{2}^{-}$concentration was $65 \mu \mathrm{mol} \mathrm{L}^{-1}$ at Station 1 in January 2005 and it decreased seaward as salinity increased. In March 2006 and 

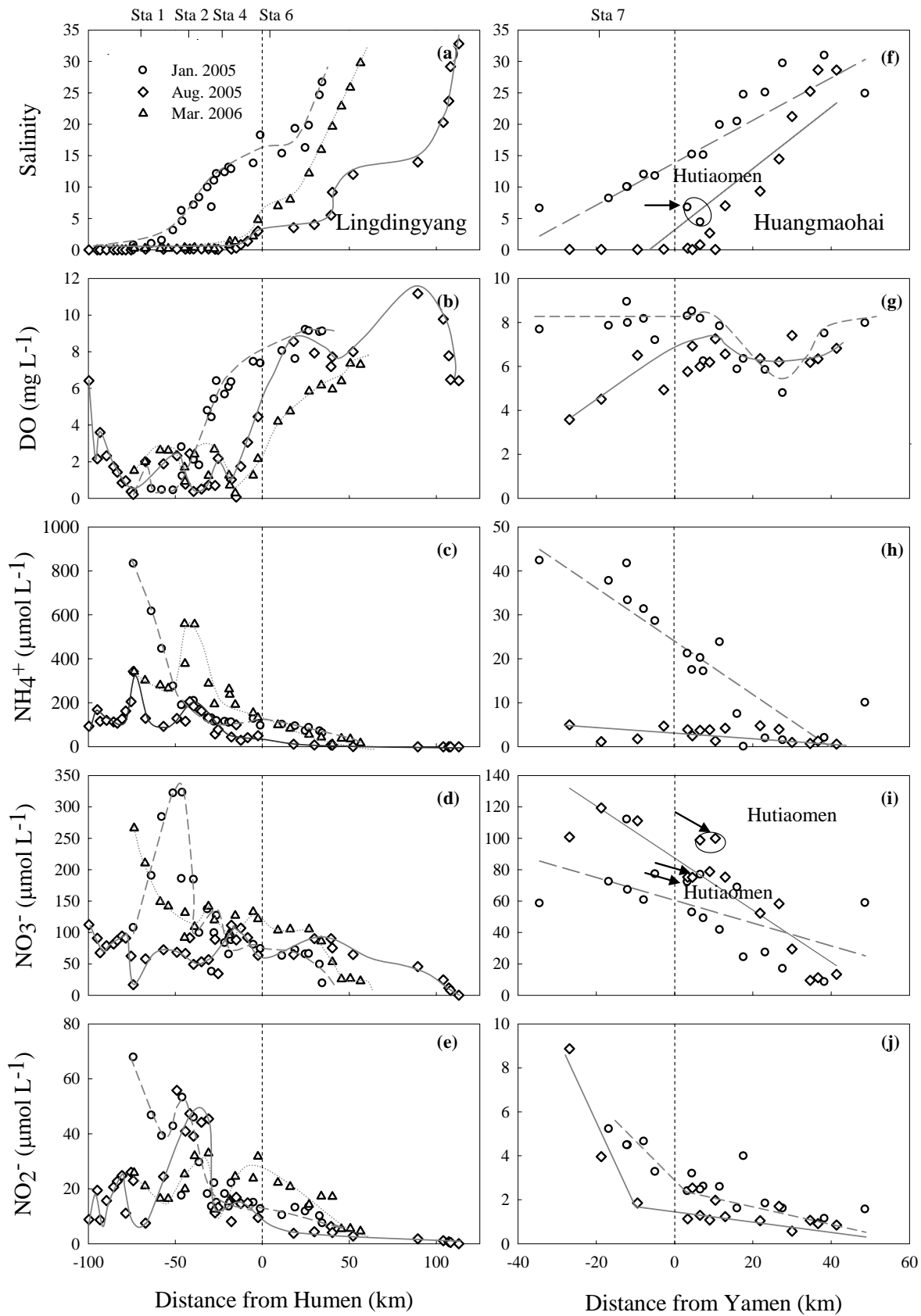

Fig. 3. Salinity, DO and inorganic nitrogen vs. distance from Humen or Yamen along the sampling transects in this study. The broken vertical lines represent the location of the Humen and Yamen outlets. Positive numbers denote downstream and negative values are upstream of the outlets. The left panels are for the Lingdingyang sub-estuary and the right ones are for the Huangmaohai sub-estuary.

August 2005, the highest $\mathrm{NO}_{2}^{-}$concentrations appeared at the sites where branches of the East River merge to the main channel (Fig. 3e). In March 2006, $\mathrm{NO}_{2}^{-}$concentration was lowest, with a maximum of $30 \mu \mathrm{mol} \mathrm{L}^{-1}$, although the concentrations of $\mathrm{NH}_{4}^{+}$and $\mathrm{NO}_{3}^{-}$were not the lowest among the seasons surveyed.

Surface DO was $>6 \mathrm{mg} \mathrm{L}^{-1}$ in the vicinity of the Humen Outlet (Station 6) and decreased upstream in January 2005.
At Station 2, DO was $<1 \mathrm{mg} \mathrm{L}^{-1}$, similar to what is reported for February 2004 (Dai et al., 2006). In August 2005, surface DO ranged from $\sim 4.5 \mathrm{mg} \mathrm{L}^{-1}$ at Station 6 to near zero at Station 2. Among the three cruises, the low DO area was largest in March 2006 (Fig. 3b). The most oxygen depleted zone (always $<3 \mathrm{mg} \mathrm{L}^{-1}$ ) was between Stations 4 and 2, where branches of the East River merge into the main channel of the Pearl River. DO concentration remained at a level of 

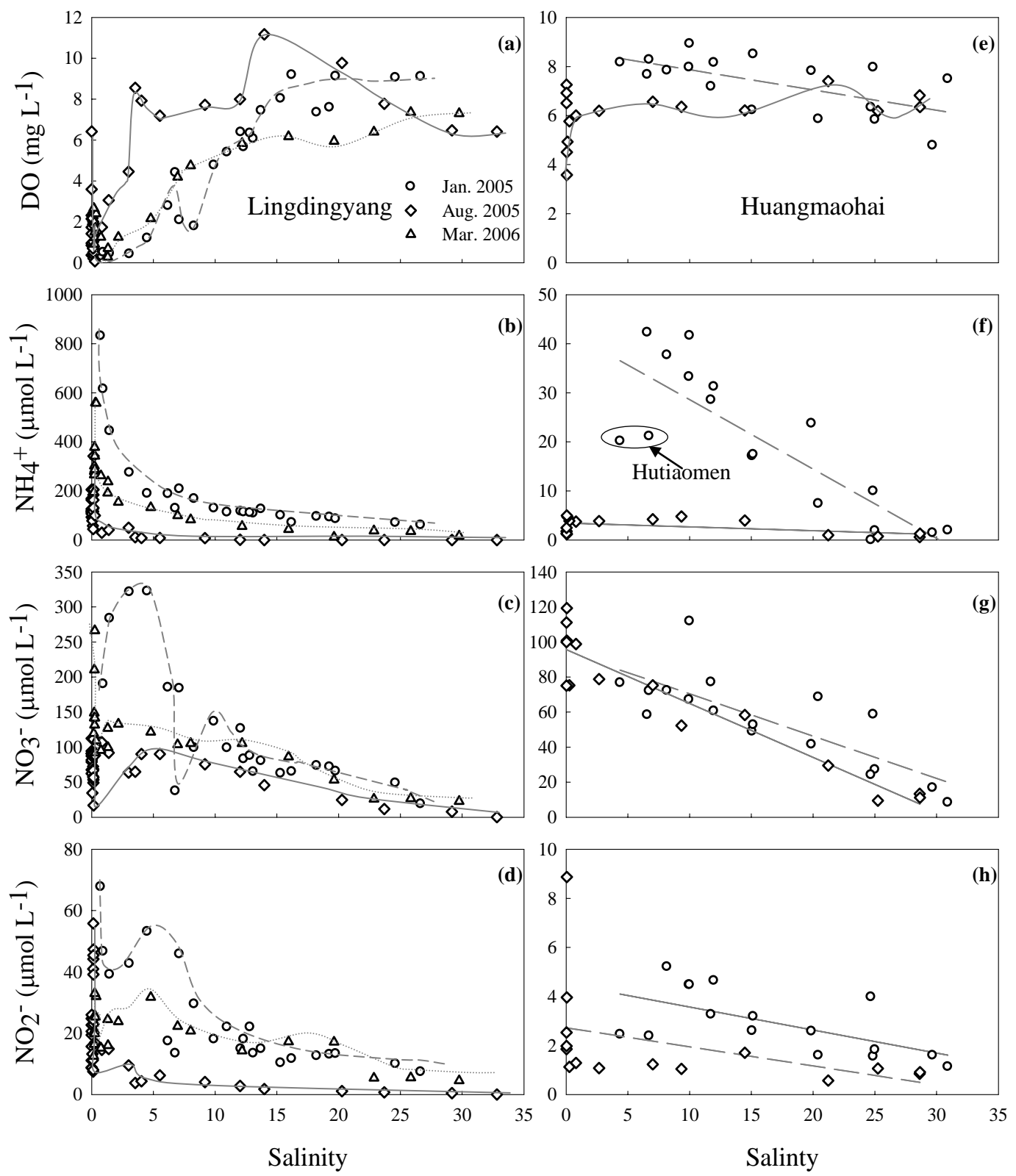

Fig. 4. Dissolved oxygen and dissolved inorganic nitrogen vs. salinity along the Humen and Yamen transects.

1-2 $\mathrm{mg} \mathrm{L}^{-1}$ at the upstream Humen in March 2006. DO concentration between Stations 1 and 2 was slightly higher than at the area between Stations 2 and 4 in the summer cruise, implying the input of oxygenated freshwater. It is interesting to note that in March 2006, DO concentrations in areas around Station 6 were the lowest among the three seasons. In all three seasons, DO concentration along the salinity gradient of the estuary ranged from hypoxic conditions at low salinity to nearly saturated in the Lingdingyang. Saturation was overall lower in summer due mainly to the higher water temperature. It should also be noted that DO at salinity $\sim 15$ in August 2005 was very high (Fig. 4a), likely due to a regional algal bloom, where partial pressure of $\mathrm{CO}_{2}\left(p \mathrm{CO}_{2}\right)$ was as low as $180 \mu \mathrm{atm}$ (Dai, unpublished data) as a result of enhanced photosynthesis. During all seasons, estuarine water upstream of the Humen was well mixed but stratified downstream as seen from the salinity and temperature vertical distribution as well as from the vertical profiles of both DO and nutrients (data not shown).

In the Huangmaohai sub-estuary (right panels in Fig. 3), DO concentrations mostly remained $>\sim 6 \mathrm{mg} \mathrm{L}^{-1}$ in the upstream Yamen (Figs. 3g, 4e); yet, lower DO concentrations were found seaward around the sand bars (see Fig. 1b, c), which might be caused by local circulation 


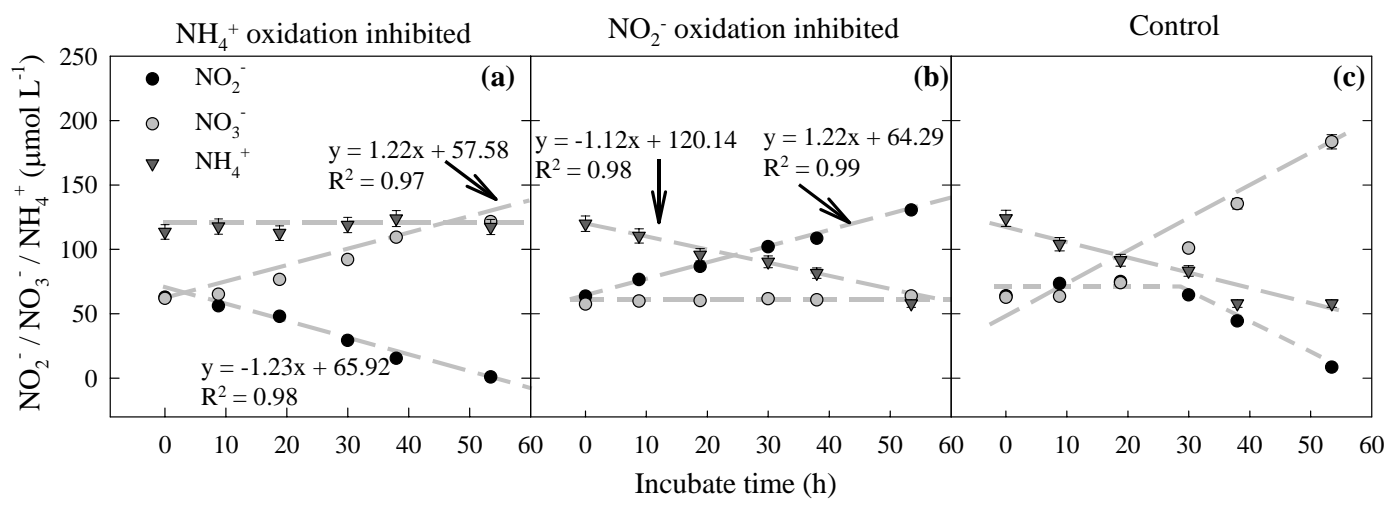

Fig. 5. Evolution of ammonium $\left(\mathrm{NH}_{4}^{+}\right)$, nitrite $\left(\mathrm{NO}_{2}^{-}\right)$, and nitrate $\left(\mathrm{NO}_{3}^{-}\right)$concentrations in the course of nitrification incubation for samples taken from Station 2 in August 2005. (a) oxidation of ammonium inhibited; (b) oxidation of nitrite inhibited; (c) control samples without any inhibitors.

and re-suspension. Similar to what was observed in the Lingdingyang, all inorganic nitrogen concentrations decreased with increasing salinity in the Huangmaohai subestuary, yet concentrations were much lower and the distribution pattern was much simpler due to less sewage input. In the Huangmaohai, both $\mathrm{NO}_{3}^{-}$and $\mathrm{NH}_{4}^{+}$followed theoretical conservative mixing (Fig. $4 \mathrm{f}-\mathrm{g}$ ). Compared to the winter cruise, $\mathrm{NH}_{4}^{+}$concentrations in August 2005 were much lower $\left(<5 \mu \mathrm{mol} \mathrm{L}{ }^{-1}\right)$ due to runoff dilution; however, $\mathrm{NO}_{3}^{-}$ concentrations were slightly higher. This inverse trend was attributable to the enhanced nitrification process and runoff dilution in summer. In contrast to the upstream Humen, nitrate was the dominant species of inorganic nitrogen in the upper reaches of the Huangmaohai sub-estuary (Fig. 3h-j). This pattern should be due to the higher oxygen content in the water column.

\subsection{Nitrifying activity and nitrifiers}

Figure 5 shows an example of the evolution of $\mathrm{NO}_{2}^{-}, \mathrm{NH}_{4}^{+}$ and $\mathrm{NO}_{3}^{-}$during the incubation experiment for the determination of nitrification rates. In this example, a sample was taken from the surface at Station 2 in August 2005. With the addition of ATU, and hence an inhibition of $\mathrm{NH}_{4}^{+}$oxidation, this sample showed a linear decrease in $\mathrm{NO}_{2}^{-}$with an increase in $\mathrm{NO}_{3}^{-}$, while $\mathrm{NH}_{4}^{+}$stayed constant (Fig. 5a). This suggests the production of $\mathrm{NO}_{3}^{-}$from $\mathrm{NO}_{2}^{-}$. In contrast, there was a linear $\mathrm{NH}_{4}^{+}$decrease and $\mathrm{NO}_{2}^{-}$increase with no change of $\mathrm{NO}_{3}^{-}$in the sample when $\mathrm{NaClO}_{3}$ was added, indicating that $\mathrm{NO}_{2}^{-}$oxidation was efficiently blocked by $\mathrm{NaClO}_{3}$ as expected (Fig. 5b). On the other hand, decreases in both $\mathrm{NO}_{2}^{-}$and $\mathrm{NH}_{4}^{+}$and an increase in $\mathrm{NO}_{3}^{-}$appeared to be due to the oxidation sequence from $\mathrm{NH}_{4}^{+}$to $\mathrm{NO}_{2}^{-}$and then to $\mathrm{NO}_{3}^{-}$in the control sample (Fig. 5c). The changing rate of $\mathrm{NH}_{4}^{+}$in the control was similar to the sample with $\mathrm{NaClO}_{3}$ added, while the rate of $\mathrm{NO}_{2}^{-}$change in the control apparently represented the difference resulting from the two reactions. It should be noted that $\mathrm{NO}_{2}^{-}$in the control showed nearly no change at the beginning of the incubation due to the fact that the changing rate of $\mathrm{NO}_{2}^{-}$in the $\mathrm{NaClO}_{3}$ added sample was almost equal to that in the ATU added sample. After this initial stage, $\mathrm{NO}_{2}^{-}$in the control decreased when most of the $\mathrm{NH}_{4}^{+}$was consumed. Throughout the incubation experiment, all three species of inorganic nitrogen presented a constant sum (data not shown) indicating that a mass balance was reached during the transformation among nitrogen species, which strongly supported that our incubation experiments and analytical measurements were in order. The $\mathrm{NH}_{4}^{+}$ and $\mathrm{NO}_{2}^{-}$oxidation rates can therefore be estimated from the linear regression of nitrite in $\mathrm{NaClO}_{3}$ or ATU added samples, respectively. The incubation experiment suggested a decline of the nitrification rate after $60 \mathrm{~h}$, and so the last data point was excluded from the rate calculation.

Table 3 lists the nitrification rates from all the incubation experiments and concurrent inorganic nitrogen concentrations during sampling. The $\mathrm{NH}_{4}^{+}$oxidation rate ranged from 0 to $5.4 \mu \mathrm{mol} \mathrm{N} \mathrm{L} \mathrm{N}^{-1} \mathrm{~d}^{-1}$ in January 2005, 0.1 to $14.8 \mu \mathrm{mol} \mathrm{N} \mathrm{L}{ }^{-1} \mathrm{~d}^{-1}$ in March 2006 and 1.5 to $33.1 \mu \mathrm{mol} \mathrm{N}$ $\mathrm{L}^{-1} \mathrm{~d}^{-1}$ in August 2005. Similarly, the $\mathrm{NO}_{2}^{-}$oxidation rate ranged from 0 to $5.2 \mu \mathrm{mol} \mathrm{N} \mathrm{L}{ }^{-1} \mathrm{~d}^{-1}$ in January 2005, 0.2 to $5.2 \mu \mathrm{mol} \mathrm{N} \mathrm{L}{ }^{-1} \mathrm{~d}^{-1}$ in March 2006 and 0.6 to $32.0 \mu \mathrm{mol}$ $\mathrm{N} \mathrm{L}^{-1} \mathrm{~d}^{-1}$ in August 2005. The maximum nitrification rate appeared at Station 2. $\mathrm{NH}_{4}^{+}$and $\mathrm{NO}_{2}^{-}$oxidation rates varied concomitantly showing similar spatial distributional patterns in all seasons. It is noticeable that the $\mathrm{NH}_{4}^{+}$oxidation rate was higher than the $\mathrm{NO}_{2}^{-}$oxidation rate at most stations regardless of season. Such difference may cause $\mathrm{NO}_{2}^{-}$ accumulations. The nitrification activity in the end of the south branch of the East River (Station 5) was high, and the $\mathrm{NH}_{4}^{+}$oxidation rate reached $5.9 \mu \mathrm{mol} \mathrm{N} \mathrm{L}{ }^{-1} \mathrm{~d}^{-1}$ in March 2006 and $33.1 \mu \mathrm{mol} \mathrm{N} \mathrm{L}{ }^{-1} \mathrm{~d}^{-1}$ in August 2005. At Station $2, \mathrm{NH}_{4}^{+}$and $\mathrm{NO}_{2}^{-}$oxidation rates showed insignificant 
Table 3. Ammonia oxidation rate (Va), total suspended solids (TSS), nitrite oxidation rate (Vn), and other parameters at all incubation stations.

\begin{tabular}{|c|c|c|c|c|c|c|c|c|c|}
\hline \multirow{2}{*}{ Location } & \multirow{2}{*}{ Station } & \multirow{2}{*}{ Dates } & \multicolumn{2}{|c|}{ Nitrifying activity $\left(\mu \mathrm{mol} \mathrm{N} \mathrm{L}^{-1} \mathrm{~d}^{-1}\right)$} & \multirow{2}{*}{$\mathrm{NO}_{2}^{-}$} & \multirow{2}{*}{$\begin{array}{r}\mathrm{NH}_{4}^{+} \\
\mu \mathrm{mol} \mathrm{L}\end{array}$} & \multirow{2}{*}{$\mathrm{NO}_{3}^{-}$} & \multirow{2}{*}{$\begin{array}{c}\text { Nitrifier } \\
\left(\text { cell } \mathrm{mL}^{-1}\right)\end{array}$} & \multirow{2}{*}{$\begin{array}{c}\text { TSS } \\
\left(\mathrm{mg} \mathrm{L}^{-1}\right)\end{array}$} \\
\hline & & & $\mathrm{Va}$ & $\mathrm{Vn}$ & & & & & \\
\hline \multirow{8}{*}{ Upstream Guangzhou } & \multirow{3}{*}{ Station 1} & Jan 2005 & 3.9 & 4.6 & 67.8 & 832.1 & 107.1 & 950 & - \\
\hline & & Aug 2005 & 12.5 & 1.5 & 23.1 & 341.9 & 16.7 & 20 & 37.0 \\
\hline & & Mar 2006 & 2.9 & 2.2 & 25.8 & 341.9 & 266.2 & 3500 & 16.8 \\
\hline & \multirow{3}{*}{ Station 2 (surface) } & Jan 2005 & 5.4 & 5.2 & 17.4 & 188.3 & 185.3 & 2500 & - \\
\hline & & Aug 2005 & 31.5 & 29.5 & 65.0 & 111.5 & 60.4 & 20 & 49.0 \\
\hline & & Mar 2006 & 10.1 & 5.2 & 19.9 & 377.8 & 131.5 & 3000 & 20.4 \\
\hline & \multirow{2}{*}{ Station 2 (bottom) } & Aug 2005 & 28.2 & 32.0 & 65.8 & 100.1 & 62.0 & 20 & - \\
\hline & & Mar 2006 & 14.8 & 3.0 & 18.8 & 367.1 & 133.2 & 3500 & - \\
\hline \multirow{7}{*}{ Downstream Guangzhou } & \multirow{2}{*}{ Station 3} & Aug 2005 & 1.5 & 0.6 & 13.4 & 62.7 & 62.7 & 165 & 35.4 \\
\hline & & Mar 2006 & 0.1 & 0.2 & 6.8 & 133.7 & 102.1 & 200 & 25.8 \\
\hline & \multirow{3}{*}{ Station 4} & Jan 2005 & 0.0 & 0.0 & 20.6 & 100.5 & 95.0 & 12 & - \\
\hline & & Mar 2006 & 0.3 & 0.4 & 16.0 & 236.9 & 99.4 & 35 & - \\
\hline & & Aug 2005 & 4.1 & 1.0 & 9.8 & 58.6 & 42.7 & 2 & 23.9 \\
\hline & \multirow{2}{*}{ Station 5} & Aug 2005 & 33.1 & 12.1 & 7.3 & 61.0 & 97.2 & 1150 & 35.1 \\
\hline & & Mar 2006 & 5.9 & 3.3 & 15.2 & 261.8 & 95.3 & 1650 & 21.3 \\
\hline \multirow{2}{*}{ Downstream Humen } & \multirow{2}{*}{ Station 6} & Aug 2005 & 3.9 & 1.1 & 11.2 & 50.2 & 74.3 & 10 & 16.2 \\
\hline & & Mar 2006 & 12.5 & 5.0 & 31.7 & 132.2 & 121.5 & 200 & 51.2 \\
\hline Yamen & Station 7 & Aug 2005 & 0.0 & 1.6 & 4.0 & 1.2 & 119.4 & 165 & 42.8 \\
\hline
\end{tabular}

differences between bottom and surface samples. Similarly, hydro-chemical parameters showed insignificant differences in depth profiles (data not shown), suggesting that nitrification took place throughout the water column.

At Station 2 upstream Humen, the highest $\mathrm{NH}_{4}^{+}$oxidation rate occurred in August 2005, 2-3 times higher than that in March 2006, and 5-6 times higher than that in January 2005. The nitrite oxidation rate did not show such a significant sequence. At another station (Station 6) downstream Humen and in the upper Lingdingyang, the nitrification rate peaked in March 2006 rather than in August 2005. In comparison, nitrification activities at Station 7 in the Yamen upstream of the Huangmaohai sub-estuary showed a very low rate in August 2005 (Table 3). Figure 6c presents the sectional nitrification rates, classifying the study area into the upstream Guangzhou, downstream Guangzhou, and downstream Humen for the Lingdingyang sub-estuary; and the result from the upstream Yamen is also shown. The mean nitrification rates declined gradually seaward from the upstream Guangzhou, the region most impacted by regional wastewater discharges.

Compared to other estuaries in the world with low $\mathrm{NH}_{4}^{+}$ concentrations, the nitrification rate in the Pearl River Estuary is high. For example, in the Rhone River plume, a nitrification rate of $0.2-2.2 \mu \mathrm{mol} \mathrm{N} \mathrm{L} \mathrm{N}^{-1} \mathrm{~d}^{-1}$ at $\mathrm{NH}_{4}^{+} \sim 1-$ $10 \mu \mathrm{mol} \mathrm{L}^{-1}$ is reported (Bianchi et al., 1997). Similarly in the Tamar Estuary with $\mathrm{NH}_{4}^{+} \sim 5 \mu \mathrm{mol} \mathrm{L}{ }^{-1}$, a nitrification rate of up to $3 \mu \mathrm{mol} \mathrm{N} \mathrm{L}{ }^{-1} \mathrm{~d}^{-1}$ is reported (Owens, 1986). In Narragansett Bay, this level is $0.9-11.0 \mu \mathrm{mol} \mathrm{N} \mathrm{L}^{-1} \mathrm{~d}^{-1}$ at $\mathrm{NH}_{4}^{+} \sim 45 \mu \mathrm{mol} \mathrm{L}^{-1}$ (Berounsky and Nixon, 1990). However, nitrification rates in the Pearl River Estuary were lower than estuaries with high $\mathrm{NH}_{4}^{+}$concentrations, such as in the Scheldt Estuary, where the nitrification rate is reported to be $\sim 45-80 \mu \mathrm{mol} \mathrm{N} \mathrm{L}-1 \mathrm{~d}^{-1}$ at a $\mathrm{NH}_{4}^{+}$concentration of $150-$ $500 \mu \mathrm{mol} \mathrm{L}^{-1}$ (de Bie et al., 2002; Somville, 1984). Elsewhere in the turbid water and fluid mud of the Gironde Estuary, the potential nitrification rate is very high, reaching 240-336 $\mu$ mol N L ${ }^{-1} \mathrm{~d}^{-1}$, although the $\mathrm{NH}_{4}^{+}$concentration in the fluid mud is $<15 \mu \mathrm{mol} \mathrm{L}^{-1}$ (Abril et al., 2000). This may suggest that nitrification reactions are also modulated by other environmental factors in addition to $\mathrm{NH}_{4}^{+}$being the primary substrate. This will be further addressed in the Discussion section.

The abundance of nitrifying bacteria in the water column of the Pearl River Estuary had a range of 2-2500 cells $\mathrm{mL}^{-1}$, 3-3000 cells $\mathrm{mL}^{-1}$ and $2-1150$ cells $\mathrm{mL}^{-1}$, respectively, in January 2005, March 2006 and August 2005 (Fig. 6). The density of nitrifying bacteria was overall high in spring (March 2006) and low in summer (August 2005), while the level in winter was intermediate. The highest nitrifier densities occurred at the upstream Guangzhou with low DO (Fig. 6). Nitrifier populations in most observed stations showed a dramatic decrease with increasing salinity in the Lingdingyang sub-estuary in all seasons. In summer and spring, the whole water column had an approximately similar nitrifier density (Table 3). The distribution pattern in nitrifier abundance was broadly consistent with that of the nitrification rates based on section category (Fig. 6). 

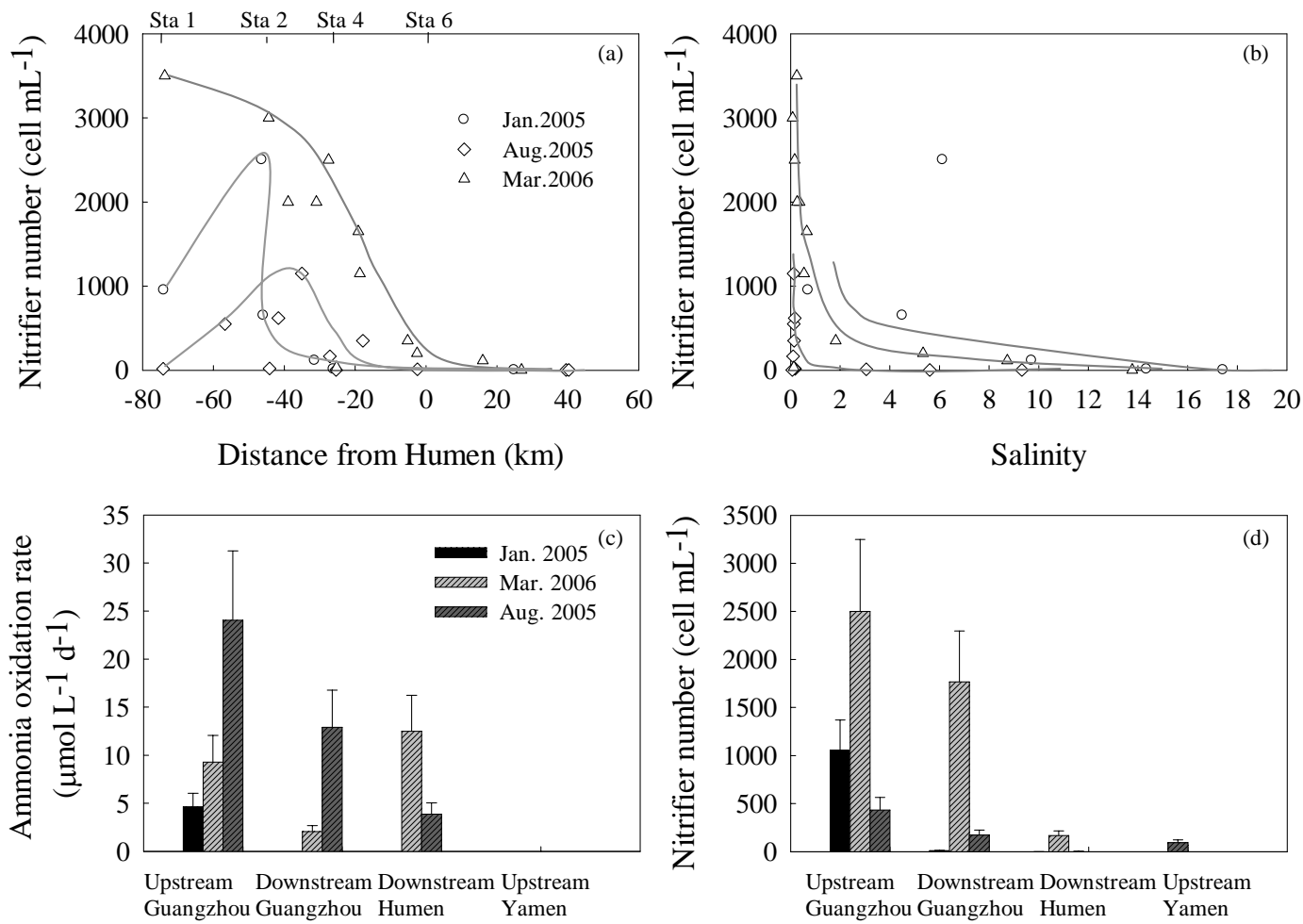

Fig. 6. Spatial distribution of nitrifier and ammonia oxidation rates in the Pearl River Estuary. (a) Nitrifier density vs. distance from the Humen; (b) Nitrifier density vs. salinity along the Humen transects; (c) Sectional distribution of ammonia oxidation rate; and (d) Sectional distribution of nitrifier density; Upstream of Guangzhou is defined as a distance of -100 to $-30 \mathrm{~km}$ from the Humen; downstream of Guangzhou is defined as a distance of 0 to $-30 \mathrm{~km}$ from the Humen; downstream of the Humen is defined as a distance $>0 \mathrm{~km}$; upstream of the Yamen is defined as a distance $<0 \mathrm{~km}$ from the Yamen.

Compared to other estuaries in the world, the maximum nitrifier density observed in the water column of the Pearl River Estuary was $3 \times 10^{3}$ cell $\mathrm{mL}^{-1}$, which is close to the level in the fluid mud of the Gironde Estuary $\left(4 \times 10^{3}\right.$ cell $\mathrm{mL}^{-1}$ ) (Abril et al., 2000), but much lower than that in the Seine Estuary (Cébron and Garnier, 2005), where the nitrifier density is $3 \times 10^{7}$ cell $\mathrm{mL}^{-1}$.

The maximum total prokaryote density was $2.9 \times 10^{6}$ cell $\mathrm{mL}^{-1}$ and $2.63 \times 10^{6}$ cell $\mathrm{mL}^{-1}$ in March 2006 and August 2005, respectively, in the pelagic waters of the Pearl River Estuary (Zhang and Jiao, unpublished data), the highest of which was also located at the upstream Humen. Bacterial density gradually decreased downstream due to mixing with the low-nutrient seawater, and the density dropped to $3.6 \times 10^{5}$ cell $\mathrm{mL}^{-1}$ and $7.7 \times 10^{5}$ cell mL $\mathrm{mL}^{-1}$ at the sea end in March 2006 and August 2005, respectively. The distribution of total prokaryotes against salinity was similar to the nitrifiers, although the ratio of nitrifiers to total prokaryotes was low.

\section{Discussion}

4.1 Interrelationship between nitrification and environmental conditions

Nitrification is typically composed of two reactions: ammonia oxidation (Eq. 1) and nitrite oxidation (Eq. 2):

$\mathrm{NH}_{3}+\mathrm{O}_{2} \rightarrow \mathrm{NO}_{2}^{-}+3 \mathrm{H}^{+}+2 e^{-}$
$\mathrm{NO}_{2}^{-}+\mathrm{H}_{2} \mathrm{O} \rightarrow \mathrm{NO}_{3}^{-}+2 \mathrm{H}^{+}+2 e^{-}$

Nitrosomonas is the most frequently identified genus associated with the first step of nitrification, i.e. ammonia oxidation, although other genera, including Nitrosococcus, $\mathrm{Ni}$ trosospira and some subgenera, Nitrosolobus and Nitrosovibrio, can also autotrophically oxidize ammonia. Nitrobacter is the most frequently identified genus associated with the second step of the process, i.e. nitrite oxidation, although other genera, including Nitrospina, Nitrococcus and Nitrospira, can also autotrophically oxidize nitrite. After all, nitrifiers are obligate for nitrification reactions and are commonly observed in terrestrial and aquatic environments (Holt et al., 1995). Their growth rates are controlled by substrate (ammonia- $\mathrm{N}$ ) concentrations, temperature, $\mathrm{pH}$, light, 

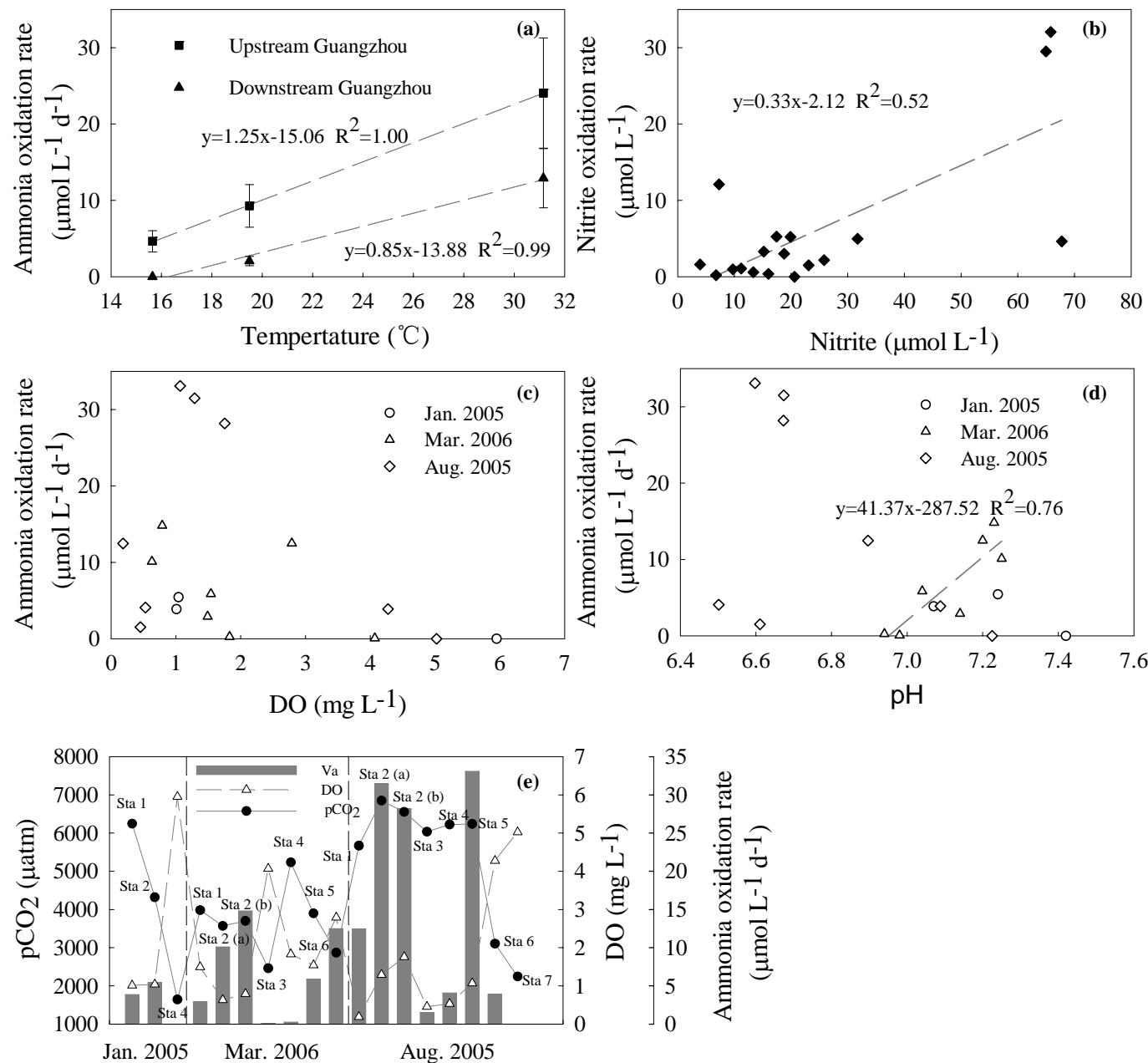

Fig. 7. Interrelationship between ammonia oxidation rates and environmental variables. (a) Average ammonia oxidation rates upstream and downstream of Guangzhou vs. temperature during all cruises; (b) nitrite oxidation rates vs. nitrite concentration for all cruises; (c) ammonia oxidation rates vs. DO concentration for different cruises; (d) ammonia oxidation rates vs. pH. Note that the linear regression line was only shown for the spring cruise (March 2006); and (e) ammonium oxidation rates vs. $p \mathrm{CO}_{2}$ and DO for all nitrification incubation stations for all the three cruises. $p \mathrm{CO}_{2}$ data of January 2005 and August 2005 are from Dai et al. (unpublished data). $p \mathrm{CO}_{2}$ data in March 2006 are derived from dissolved inorganic carbon, total alkalinity, salinity, in situ temperature, silicate and phosphate concentration with the $\mathrm{CO}_{2} \mathrm{SYS}$ program (Lewis and Wallace, 1998).

DO, microbial abundance and community composition. In wastewater treatment systems and the soil environment, there has been extensive research on the media conditions affecting nitrifier growth and nitrification rates (e.g. Bhaskar and Charyulu, 2005; Kemmitt et al., 2006; Kesik et al., 2006; Lyssenko and Wheaton, 2006). In real aquatic systems, however, such research has been limited (Chenier et al., 2006; Dollhopf et al., 2005) due to the magnitude and the complexity of natural systems like the Pearl River Estuary. Below, we attempt to elucidate the interplay between nitrification and environmental conditions.

\subsubsection{Nitrification vs. temperature}

Much literature has documented that the nitrification rate in both marine and freshwater systems increases exponentially with temperature. For example, the nitrification rate in Narragansett Bay ranges from near zero in winter to $\sim 1 \mu \mathrm{mol} \mathrm{N}$ $\mathrm{L}^{-1} \mathrm{~d}^{-1}$ in summer, with an apparent $Q_{10} \sim 6.8\left(Q_{10}\right.$ represents the increase in the rate of a process at each $10^{\circ} \mathrm{C}$ increase in temperature (see Berounsky and Nixon, 1990)). It is reported that the mean $Q_{10}$ for the potential nitrification rate is $\sim 2.5$ within the temperature range $2-22^{\circ} \mathrm{C}$ (Hansen et al., 1981). In our study, the nitrification rate was consistently higher in summer, $\sim 2-6$ times higher than that in other seasons, except at Station 6. Especially at Station 2 
in the Guangzhou section of the Pearl River, the ammonia oxidation rate in August 2005 was $\sim 2$ times higher than that in March 2006, and $~ 3$ times higher than that in January 2005. At the same time, the surface water temperature in $\mathrm{Au}-$ gust 2005 was $15^{\circ} \mathrm{C}$ higher than in January 2005. Good correlation existed between the mean nitrification rate and temperature, exemplified in Fig. 7a, upstream and downstream of Guangzhou, suggesting a strong control of temperature on the nitrification rate. Moreover, regression of the logarithm of the $\mathrm{NH}_{4}^{+}$oxidation rate vs temperature also showed a significant positive relationship $\left(R^{2}=1.0\right)$, and the calculated apparent $Q_{10}$ value was 1.60 at Station 2, which is close to the value of $\sim 2.0$, based on the conservative estimate by the US EPA (1993). This value is also within the typical range of 1-3.5 for nitrification processes by cultured marine and freshwater nitrifiers (Jones et al., 2005). It is noteworthy that in coastal marine systems, other nitrogen species transformations such as denitrification, nitrogen fixation, phytoplankton growth, and regeneration of ammonium, are also sensitive to temperature with a $Q_{10} \sim 1.2$ to 9.4 (Berounsky and Nixon, 1990).

\subsubsection{Nitrification vs. nitrogen substrate}

Excess nitrogen in the form of ammonia may drive nitrification. As mentioned above, a dramatic decrease in $\mathrm{NH}_{4}^{+}$, an increase in $\mathrm{NO}_{3}^{-}$and the invariant $\mathrm{NO}_{2}^{-}$were observed at salinity 0 to 5 in the Pearl River Estuary in January 2005. A similar trend was observed in August 2005, when $\mathrm{NO}_{3}^{-}$ dropped to $\sim 110 \mu \mathrm{mol} \mathrm{L}^{-1}$ and remained at this level from Stations 4 to 6 despite the fact that $\mathrm{NH}_{4}^{+}$and $\mathrm{NO}_{2}^{-}$concentrations were low. High nitrifying activity dominated this section of the Pearl River Estuary between Stations 2 and 6 , which may explain the high $\mathrm{NO}_{3}^{-}$concentration at this location. In the end of the south branch of the East River, we also observed high nitrifying activity, coinciding with the decrease of $\mathrm{NH}_{4}^{+}$and increase of $\mathrm{NO}_{3}^{-}$downstream. This nitrifying activity and nutrient distribution pattern, together with the nitrogen transformation inferred, strongly supported the contribution of nitrification processes in this location. A very similar case is documented in the Delaware River (Lipschultz et al., 1986). However, being a primary substrate for nitrification, low $\mathrm{NH}_{4}^{+}$concentration may also limit the nitrification activity. For example, the nitrification activity at Station 7 in the Yamen, upstream of the Huangmaohai subestuary showed a very low rate in August 2005, which could be explained by the low level of $\mathrm{NH}_{4}^{+}\left(<5 \mu \mathrm{mol} \mathrm{L}{ }^{-1}\right)$ despite the relatively high nitrifier abundance.

It should be noted that we did not find a linear and simple correlation between the nitrifying activity and inorganic nitrogen in the Pearl River Estuary. In the winter (January 2005), the most upper reaches of the Pearl River Estuary showed relatively low $\mathrm{NH}_{4}^{+}$oxidation $(5.4 \mu \mathrm{mol} \mathrm{N}$ $\left.\mathrm{L}^{-1} \mathrm{~d}^{-1}\right)$ and $\mathrm{NO}_{2}^{-}$oxidation rates $\left(5.2 \mu \mathrm{mol} \mathrm{N} \mathrm{L} \mathrm{L}^{-1} \mathrm{~d}^{-1}\right)$.
However, this region was characterized by very high $\mathrm{NH}_{4}^{+}$ (>800 $\left.\mu \mathrm{mol} \mathrm{L}^{-1}\right)$ and $\mathrm{NO}_{3}^{-}\left(>300 \mu \mathrm{mol} \mathrm{L}^{-1}\right)$ concentrations. In summer, both surface and bottom waters of the upper estuary showed very high nitrification rates $\left(\mathrm{NH}_{4}^{+}\right.$oxidation rate $\sim 31.5 \mu \mathrm{mol} \mathrm{N} \mathrm{L}^{-1} \mathrm{~d}^{-1}, \mathrm{NO}_{2}^{-}$oxidation rate $\sim 29.5 \mu \mathrm{mol} \mathrm{N} \mathrm{L}^{-1} \mathrm{~d}^{-1}$ ) accompanied by relatively low $\mathrm{NH}_{4}^{+}$and $\mathrm{NO}_{2}^{-}$concentrations as compared to winter. Significant positive correlations between the $\mathrm{NH}_{4}^{+}$and $\mathrm{NO}_{2}^{-}$oxidation rates $\left(R^{2}=0.70\right.$, data not shown), and between $\mathrm{NO}_{2}^{-}$ oxidation rates and $\mathrm{NO}_{2}^{-}$concentration (Fig. 7b) were observed. This phenomenon elucidates the substrate effect on the nitrification rate. On the other hand, no significant correlation between $\mathrm{NH}_{4}^{+}$and $\mathrm{NO}_{2}^{-}$oxidation rates was found, which is similar to the case in the Rhone River plume and the Indian sector of the Southern Ocean (Bianchi et al., 1994, 1997).

\subsubsection{Nitrification vs. nitrifier activity}

Nitrifier abundance is reflective of nitrification potential. As shown in Fig. 6c-d, the distribution of the nitrification rate was overall consistent with that of nitrifier abundance, except at the downstream Humen in March 2006, when a low nitrifier density was associated with a higher nitrifying activity. In addition, nitrifier densities at Station 2 were relatively low but with the highest nitrifying activity when compared with other stations in August 2005 (Table 3). The low nitrifier densities and high ammonium oxidation rate revealed a much greater specific nitrification rate per cell. There are other reports on similar cases. In Lake St. George, less than 1-2 cells $\mathrm{mL}^{-1}$ are found, but it would need a nitrifier population of $1.6 \times 10^{2}-1.0 \times 10^{4}$ cells $\mathrm{mL}^{-1}$ according to the in situ nitrifying activity of $13 \mu \mathrm{g} \mathrm{N} \mathrm{L}{ }^{-1} \mathrm{~d}^{-1}$ (Knowles and Lean, 1987).

It should be pointed out that most nitrifiers are attached to particles (Stehr et al., 1995). Particle aggregates provide microsites in which oxygen concentrations are usually lower than that in the surrounding waters, and this favors bacterial growth. The accumulation of particles in estuaries is shown to enhance the growth of the nitrifying population and nitrifying activity in the Gironde, Seine and Yellow River/Estuary (Abril et al., 2000; Brion et al., 2000; Xia et al., 2004). In August 2005, Station 2 showed a high nitrification rate despite a relatively low nitrifier density, which may be due to the high turbidity (total suspended solids (TSS) up to be $49 \mathrm{mg} \mathrm{L}^{-1}$ ). In March 2006, nitrifier densities and inorganic nitrogen were low at Station 6 located at the downstream $\mathrm{Hu}$ men as compared to other stations, however it showed moderate nitrifying activity, which may be explained again by the high TSS (Table 3). Finally, it must be pointed out that our MNP method for determining nitrifier abundance does not distinguish between the two groups of nitrifiers. 


\subsection{Nitrification and community oxygen consumption}

Coupling the two oxidation processes (Eqs. 1 and 2) and assimilation reactions, the overall reaction describing the complete nitrification process should be (see Dai et al., 2006, after US EPA, 1993):

$$
\begin{aligned}
& \mathrm{NH}_{4}^{+}+1.89 \mathrm{O}_{2}+1.98 \mathrm{HCO}_{3}^{-} \rightarrow \\
& \quad 0.984 \mathrm{NO}_{3}^{-}+0.016 \mathrm{C}_{5} \mathrm{H}_{7} \mathrm{O}_{2} \mathrm{~N}+1.90 \mathrm{CO}_{2}+2.93 \mathrm{H}_{2} \mathrm{O}
\end{aligned}
$$

The stoichiometric coefficients imply that 1 mole $\mathrm{NH}_{4}^{+}$removal through nitrification required a 1.98 mole of TAlk consumption and produced 1.90 mole of free $\mathrm{CO}_{2}$. Implied from the above reaction is that the carbonate system was greatly related to the nitrification process, which consumes oxygen and produces free $\mathrm{CO}_{2}$ and hence acid. Below we further elucidate the importance of nitrification in community oxygen consumption in our system.

Oxygen is essential during both the ammonia and nitrite oxidation processes (Deri, 1991). DO, as the growth-limiting substrate, its values for the half-saturation coefficient are reported as $0.15-2.0 \mathrm{mg} \mathrm{L}^{-1}$ in biological waste treatment systems (US EPA, 1993). Nitrification reactions typically happen within a DO range of $0.5-2.5 \mathrm{mg} \mathrm{L}^{-1}$ although they can still proceed at a DO level as low as $0.05 \mathrm{mg} \mathrm{L}^{-1}$ (Abeliovich, 1987). Under certain conditions, nitrification can impose significant oxygen demands leading to localized oxygen minima in the upper reaches of estuaries (Balls et al., 1996).

Here in the Pearl River Estuary, we found complex relationships between DO and nitrification rates, but an overall reverse trend was observed in all seasons and most of the higher ammonia oxidation rates were associated with a DO range of $0.5-2.5 \mathrm{mg} \mathrm{L}^{-1}$ (Fig. 7c), consistent with the previous studies mentioned above. The decrease in DO concentration also coincided with an increase in $\mathrm{NO}_{2}^{-}$in most cases, which may suggest that DO is one of the most important factors interplaying with nitrification in the Pearl River Estuary. At Station 6 DO concentration was lowest in March 2006, while the nitrification rate was the highest among the three surveyed seasons (Fig. 3 and Table 3). This suggests that nitrification may represent an important mechanism contributing to $\mathrm{O}_{2}$ consumption.

In fact, nitrification-induced DO consumption has been reported previously. Nitrification accounts for around $25 \%$ of the total biological oxygen demand in the West Schelde Estuarine maximum turbidity zone and for $>20 \%$ in the water column (Pakulski et al., 1995; Soetaert and Herman, 1995). Capers (1981) reports that intense nitrification is correlated with a depletion of the oxygen concentration in a large zone of the freshwater section in the Elbe Estuary. In the Mississippi River plume, DO consumption associated with potential nitrification amounts to $20-34 \%$ of the community DO consumption at the mid-salinity zone (Pakulski et al., 1995). At Lake St. George, nitrification even results in $71 \%$ of average oxygen consumption under winter ice, and promotes oxygen depletion and possibly fish kills in winter (Knowles and Lean, 1987).

It must be pointed out that the DO level and its consumption involves many complex processes, such as aerobic respiration, water residence times, and air-sea oxygen exchanges (Dai et al., 2006; Griffith et al., 1990; Hopkinson et al., 1989; Zhai et al., 2005). The contribution of nitrification to DO consumption is typically confined to a narrow range of an estuarine zone, such as in the upper reaches. In the present study, if we assumed that nitrification consumed $1.4 \mathrm{~mol}$ and $0.5 \mathrm{~mol} \mathrm{O}_{2}$ when oxidizing $1 \mathrm{~mol}$ of $\mathrm{NH}_{4}^{+}$and $1 \mathrm{~mol}$ of $\mathrm{NO}_{2}^{-}$, then DO consumption caused by nitrification was $0.3 \mu \mathrm{mol}$ $\mathrm{O}_{2} \mathrm{~L}^{-1} \mathrm{~h}^{-1}$ in January 2005, $0.7 \mu \mathrm{mol} \mathrm{O} \mathrm{L}^{-1} \mathrm{~h}^{-1}$ in March 2006 and $2.5 \mu \mathrm{mol} \mathrm{O}_{2} \mathrm{~L}^{-1} \mathrm{~h}^{-1}$ in August 2005 at Station 2. At Station 1, this value was $0.4 \mu \mathrm{mol} \mathrm{O} \mathrm{L}^{-1} \mathrm{~h}^{-1}$ in January 2005. At the same time, the total oxygen consumption rate was $2.7 \mu \mathrm{mol} \mathrm{O} \mathrm{L}^{-1} \mathrm{~h}^{-1}$ at Station 2 in March 2006 and $7.5 \mu \mathrm{mol} \mathrm{O} \mathrm{L}^{-1} \mathrm{~h}^{-1}$ in August 2005. Therefore, the ratio between $\mathrm{O}_{2}$ consumption due to nitrification and community $\mathrm{O}_{2}$ consumption was $\sim 33 \%$ and $\sim 26 \%$ for summer and spring, respectively, at Station 2. Although this ratio cannot represent the entire Pearl River Estuary and the respiration process involved a complex suit of variables, what can be certain is that community $\mathrm{O}_{2}$ consumption by nitrification was significant in the upper Pearl River Estuary. Heterotrophic bacteria are generally considered to be the principal consumers of $\mathrm{O}_{2}$ in marine ecosystems. As a comparison, Jensen et al. (1990) report that organisms other than heterotrophic bacteria are responsible for $>50 \%$ of community $\mathrm{O}_{2}$ consumption in a highly eutrophic region of the shallow Danish Estuary. So we assert that heterotrophic bacteria and other organisms (zooplankton, protozoa etc.) consumed most $\mathrm{O}_{2}$ in spring or winter, while nitrifiers were the key consumers of DO in summer in the upper Pearl River Estuary.

As is shown by the formation of hydrogen ions (acid) in Eqs. (1) and (2), reductions in $\mathrm{pH}$ and alkalinity are expected to inhibit the nitrification reaction. An ideal $\mathrm{pH}$ range for nitrification is between 7.5 and 8.5 (Engel and Alexander, 1958; Wild et al., 1971) although nitrifying bacteria can adapt to environments outside this range. Alkalinity is also consumed during the nitrification process and thus sufficient alkalinity must be present to buffer the acids produced during nitrification. A number of studies have suggested that $\mathrm{NH}_{4}^{+}$oxidation might be inhibited at low $\mathrm{pH}$. Huesemann et al. (2002) found that relative to $\mathrm{pH} 8$, the nitrification rate dramatically drops with $\mathrm{pH}$, by $\sim 50 \%$ at $\mathrm{pH} 7$ and by $>90 \%$ at pH 6.5 when incubating seawater samples taken from either the euphotic or aphotic zone. Srna and Baggaley (1975) report a $\sim 50 \%$ reduction in marine ammonium oxidation rates when $\mathrm{pH}$ drops from 7.8 to 7.3.

During our March 2006 cruise, pH ranged between 6.94 and 7.25, and the ammonia oxidation rate showed a significant positive correlation with $\mathrm{pH}$ (Fig. 7d). This trend is similar to the result observed by Huesemann (2002). However, the correlation between $\mathrm{pH}$ and nitrification did not appear to 
exist in other cruises, which again emphasized the complexity of the interplay between these two variables. $\mathrm{pH}$ is regulated by many physicochemical factors, such as $\mathrm{NH}_{4}^{+}$, total alkalinity (TAlk), dissolved inorganic carbon (DIC) concentration, acidic wastewater, biological production and respiration, as well as the fact that the Pearl River Estuary is indeed a complex system with large temporal or spatial variations of physicochemical factors.

Nitrification apparently interplayed with other carbonate parameters according to our observation in all cruises. We observed that high nitrifying activities accompany high $p \mathrm{CO}_{2}$, TAlk and DIC in the upper estuary of the Pearl River in winter (Dai et al., 2006; Guo et al., 2008). Dai et al. (2006) speculate that nitrification together with aerobic respiration contribute to the consumption of DO and may have significant impact on the distribution pattern of the carbonate system in the upper Pearl River Estuary. In summer (August 2005), our incubation experiment showed very high nitrification rates. Meanwhile, we found significant DIC change and TAlk decrease during the incubation due likely to the $\mathrm{CO}_{2}$ outgassing and nitrification for the surface or bottom water of the upper estuary (data not shown). If DIC change in the incubation was completely due to the $\mathrm{CO}_{2}$ outgassing, then the rate of DIC decrease would be equal to the rate of $\mathrm{CO}_{2}$ outgassing. The $\Delta\left[\mathrm{CO}_{2}\right] /-\Delta\left[\mathrm{NH}_{4}^{+}\right]$quotient at both the surface and bottom of Station 2 in August 2005 ranged between 1.78 and 2.33, which is close to the theoretical nitrification quotient of 1.90 shown in Eq. (3).

Taken together, $p \mathrm{CO}_{2}$ mirrored DO for all incubation stations in all seasons (Fig. 7e) though the correlation coefficient between them was not very high $\left(R^{2}=0.47\right)$. This phenomenon has been indicated previously (Dai et al., 2006; Zhai et al., 2005). Nitrification rates varied concomitantly with $p \mathrm{CO}_{2}$, particularly in summer, revealing its important role in consuming DO and producing free $\mathrm{CO}_{2}$ in the upper Pearl River Estuary.

\section{Concluding remarks}

Extremely high concentrations of $\mathrm{NH}_{4}^{+}$and depleted DO in the water sound an alarm concerning the ecosystem changes due to heavy pollution in the Pearl River Estuary. Freshwater runoff, sewage input and in-estuary nitrification processes strongly affected the concentration and relative distribution of various inorganic nitrogen forms on a spatial scale. A strong nitrification process was observed in the upper Pearl River Estuary and its intensity changed over time with the highest nitrification rate occurring in summer, when temperature was high and $\mathrm{O}_{2}$ solubility was low. Evidence from the present investigations indicated that nitrification was an important mechanism contributing to $\mathrm{O}_{2}$ consumption in the upper Pearl River Estuary, which accounted for about 20$30 \%$ of the community $\mathrm{O}_{2}$ consumption in the oxygen depleted zone. Temperature appeared to control the nitrifica- tion rate to a large degree; additionally, the nitrification rate may also have been influenced by such factors as oxygen, $\mathrm{pH}$, nitrifier density and TSS.

Acknowledgements. This work was supported by the Natural Science Foundation of China through grants \#40521003, \#40576036, \#90711005 and \#90211020. We thank Hua Lin, Yanping Xu, Hongmei Chen for their help during the sampling and data collection. We are grateful to Yao Zhang and Nianzhi Jiao for providing the prokaryote data. The crew of Yue-Dong-Guang-Yu 00589 provided much help during the sampling cruises. I. J. Hodgkiss, George T. F. Wong and T. L. Zheng provided help in the preparation of the manuscript.

Edited by: C. Slomp

\section{References}

Abeliovich, A.: Nitrifying bacteria in wastewater reservoirs, Appl. Environ. Microbiol., 54(4), 754-760, 1987.

Abril, G. and Frankignoulle, M.: Nitrogen-alkalinity interactions in the highly polluted Scheldt basin (Belgium), Water Res., 35(3), 844-850, 2001.

Abril, G., Riou, A., S., Etcheber, H., Frankignoulle, M., de Wit, R., and Middelburg, J. J.: Transient, tidal time-scale, nitrogen transformations in an estuarine turbidity maximum-fluid mud system (the Gironde, south-west France), Estuar. Coast. Shelf Sci., 50(5), 703-715, 2000.

Balls, P. W., Brockie, N., Dobson, J., and Johnston, W.: Dissolved oxygen and nitrification in the upper Forth Estuary during summer (1982-92): patterns and trends, Estuar. Coast. Shelf Sci., 42(1), 117-134, 1996.

Belser, L. W.: Population ecology of nitrifying bacteria, Ann. Rev. Microbiol., 33, 309-333, 1979.

Berounsky, V. M. and Nixon, S. W.: Temperature and the annual cycle of nitrification in waters of Narragansett Bay, Limnol. Oceanogr., 35(7), 1610-1617, 1990.

Bhaskar, K. V. and Charyulu, P.: Effect of environmental factors on nitrifying bacteria isolated from the rhizosphere of Setaria italica (L.) Beauv, Afr. J. Biotechnol., 4(10), 1145-1146, 2005.

Bianchi, M., Bonin, P., and Feliatra, F.: Bacterial nitrification and denitrification rates in the Rhone River Plume (Northwestern Mediterranean Sea), Mar. Ecol. Prog. Ser., 103(1-2), 197-202, 1994.

Bianchi, M., Feliatra, F., Treguer, P., Vincendeau, M. A., and Morvan, J.: Nitrification rates, ammonium and nitrate distribution in upper layers of the water column and in sediments of the Indian sector of the Southern Ocean, Deep-Sea Res. II, 44(5), 10171032, 1997.

Bianchi, M., Marty, D., Teyssie, J. L., and Fowler, S. W.: Strictly aerobic and anaerobic-bacteria associated with sinking particulate matter and zooplankton fecal pellets, Mar. Ecol. Prog. Ser., 88(1), 55-60, 1992.

Brion, N., Billen, G., Guezennec, L., and Ficht, A.: Distribution of nitrifying activity in the Seine River (France) from Paris to the estuary, Estuaries, 23(5), 669-682, 2000.

Cai, W. J., Dai, M. H., Wang, Y. C., Zhai, W. D., Huang, T., Chen, S. T., Zhang, F., Chen, Z. Z., and Wang, Z. H.: The biogeochemistry of inorganic carbon and nutrients in the Pearl River Estuary and 
the adjacent Northern South China Sea, Cont. Shelf Res., 24(12), 1301-1319, 2004.

Capers, H.: Seasonal effects on the nitrogen cycle in the freshwater section of the Elbe Estuary, Ver. Internat. Verein. Limnol., 21, 866-870, 1981.

Cébron, A. and Garnier, J.: Nitrobacter and nitrospira genera as representatives of nitrite-oxidizing bacteria: detection, quantification and growth along the lower Seine River (France), Water Res., 39(20), 4979-4992, 2005.

Chen, S. M. and Zheng, F. S.: Experimental Methods of Water Microbiology. Ocean Press, Beijing, 251pp, 1985 (in Chinese).

Cheng, Z.-L.: Decadal variation of hydrological status in stream network area and the eight outlets of Pearl River Delta. Acta Scientiarum Naturalium Universitatis Sunyatseni. 40 (Suppl.2), 29-31, 2001 (in Chinese).

Chenier, M. R., Beaumier, D., Roy, R., Driscoll, B. T., Lawrence, J. R., and Greer, C. W.: Influence of nutrients, hexadecane, and temporal variations on nitrification and exopolysaccharide composition of river biofilms, Can. J. Microbiol., 52(8), 786-797, 2006.

Cheung, K. C., Nie, X. P., Lan, C. Y., and Wong, M. H.: Aimen, Modaomen and Pearl River estuaries of the Pearl River Delta, in: V. LOICZ Reports and Studies, edited by: Dupra, S. V., Smith, J. I. M. C., and Crossland, C. J., LOICZ, Texel, The Netherlands, 45-52, 2000.

Dai, M. H., Guo, X. H., Zhai, W. D., Yuan, L. Y., Wang, B. W., Wang, L. F., Cai, P. H., Tang, T. T., and Cai, W. J.: Oxygen depletion in the upper reach of the Pearl River Estuary during a winter drought, Mar. Chem., 102(1-2), 159-169, 2006.

de Bie, M. J. M., Starink, M., Boschker, H. T. S., Peene, J. J., and Laanbroek, H. J.: Nitrification in the Schelde Estuary: methodological aspects and factors influencing its activity, FEMS Microbiol. Ecol., 42(1), 99-107, 2002.

de Wilde, H. P. J. and de Bie, M. J. M.: Nitrous oxide in the Schelde Estuary: production by nitrification and emission to the atmosphere, Mar. Chem., 69(3-4), 203-216, 2000.

Deri, A.: The role of nitrification in the oxygen depletion of the River Danube, Ver. Internat. Verein. Limnol., 24, 1965-1968, 1991.

Diab, S., Kochba, M., and Avnimelech, Y.: Nitrification pattern in a fluctuating anaerobic-aerobic pond environment, Water Res., 27(9), 1469-1475, 1993.

Dollhopf, S. L., Hyun, J. H., Smith, A. C., Adams, H. J., and O'Brien, S.: Quantification of ammonia-oxidizing bacteria and factors controlling nitrification in salt marsh sediments, Appl. Environ. Microbiol., 71(1), 240-246, 2005.

Engel, M. S. and Alexander, M.: Growth and autotrophic metabolism of nitrosonomas Europaea, J. Bacteriol., 76(2), 217222, 1958.

Feray, C., Volat, B., Degrange, V., Clays-Josserand, A., and Montuelle, B.: Assessment of three methods for detection and quantification of nitrite-oxidizing bacteria and nitrobacter in freshwater sediments (MPN-PCR, MPN-Griess, immunofluorescence), Microb. Ecol., 37(3), 208-217, 1999.

Galloway, J. N., Dentener, F. J., Capone, D. G., Boyer, E. W., Howarth, R. W., Seitzinger, S. P., Asner, G. P., Cleveland, C. C., Green, P. A., Holland, E. A., Karl, D. M., Michaels, A. F., Porter, J. H., Townsend, A. R., and Vorosmarty, C. J.: Nitrogen cycles: past, present, and future, Biogeochemistry, 70(2), 153-
226, 2004.

Garnier, J., Cebron, A., Tallec, G., Billen, G., Sebilo, M., and Martinez, A.: Nitrogen behaviour and nitrous oxide emission in the tidal Seine River Estuary (France) as influenced by human activities in the upstream watershed, Biogeochemistry, 77(3), 305326, 2006.

Garnier, J., Servais, P., Billen, G., Akopian, M., and Brion, N.: The oxygen budget in the Seine Estuary: balance between photosynthesis and degradation of organic matter, Estuaries, 24, 964-977, 2001.

Griffith, P. C., Douglas, D. J., and Wainright, S. C.: Metabolicactivity of size-fractionated microbial plankton in estuarine, nearshore, and continental-shelf waters of Georgia, Mar. Ecol Prog. Ser., 59(3), 263-270, 1990.

Gunnarsson, J., Bjork, M., Gilek, M., Granberg, M., and Rosenberg, R.: Effect of eutrophication on contaminant cycling in marine benthic system, Amibo, 29, 252-259, 2000.

Guo, X. H., Cai, W.-J., Zhai, W.-D., Dai, M.-H, Wang, Y.-C., and Chen, B.-S.: Seasonal variations in the inorganic carbon system in the Pearl River (Zhujiang) Estuary, Cont. Shelf Res., 28, 14241434, 2008.

Hansen, J. I., Henriksen, K., and Blackburn, T. H.: Seasonal distribution of nitrifying bacteria and rates of nitrification in coastal marine-sediments, Microb. Ecol., 7(4), 297-304, 1981.

Ho, K. C. and Hui, K. C. C.: Chemical contamination of the East River (Dongjiang) and its implication on sustainable development in the Pearl River Delta, Environ. Int., 26(5-6), 303-308, 2001.

Holt, D., Rory, D. T., Anaick, D., and Jennifer, S. C.: A study of nitrite formation and control in chloraminated distribution systems, In Proc. AWWA Water Quality Technology Conference; Part II., Denver, Colo.: AWWA, 1995.

Hopkinson, C. S., Sherr, B., and Wiebe, W. J.: Size fractionated metabolism of coastal microbial plankton, Mar. Ecol.-Prog. Ser., 51(1-2), 155-166, 1989.

Howarth, R. W., Billen, G., Swaney, D., Townsend, A., Jaworski, N., Lajtha, K., Downing, J. A., Elmgren, R., Caraco, N., Jordan, T., Berendse, F., Freney, J., Kudeyarov, V., Murdoch, P., and Zhu, Z. L.: Regional nitrogen budgets and riverine N\&P fluxes for the drainages to the North Atlantic Ocean: natural and human influences, Biogeochemistry, 35(1), 75-139, 1996.

Howarth, R. W. and Marino, R.: Nitrogen as the limiting nutrient for eutrophication in coastal marine ecosystems: Evolving views over three decades, Limnol. Oceanogr., 51(1), 364-376, 2006.

Huesemann, M. H., Skillman, A. D., and Crecelius, E. A.: The inhibition of marine nitrification by ocean disposal of carbon dioxide, Mar. Pollut. Bull., 44(2), 142-148, 2002.

Jensen, L. M., Sand, J. K., Marcher, S., and Hansen, M.: Plankton community respiration along a nutrient gradient in a shallow Danish Estuary, Mar. Ecol. Prog. Ser., 61, 75-85, 1990.

Jones, R. M., Bye, C. M., and Dold, P. L.: Nitrification parameter measurement for pliant design: experience and experimental issues CD with new methods, Water Sci. Technol., 52(10-11), 461-468, 2005.

Kemmitt, S. J., Wright, D., Goulding, K. W. T., and Jones, D. L.: pH regulation of carbon and nitrogen dynamics in two agricultural soils, Soil Biol. Biochem., 38(5), 898-911, 2006.

Kesik, M., Blagodatsky, S., Papen, H., and Butterbach-Bahl, K.: Effect of $\mathrm{pH}$, temperature and substrate on $\mathrm{N}_{2} \mathrm{O}, \mathrm{NO}$ and $\mathrm{CO}_{2}$ pro- 
duction by Alcaligenes faecalis p., J. Appl. Microbiol., 101(3), 655-667, 2006.

Knowles, R. and Lean, D. R. S.: Nitrification - a significant cause of oxygen depletion under winter ice, Can. J. Fish. Aquat. Sci., 44(4), 743-749, 1987.

Konuma, S., Satoh, H., Mino, T., and Matsuo, T.: Comparison of enumeration methods for ammonia-oxidizing bacteria, Water Sci. Technol., 43(1), 107-114, 2001.

Koops, H.-P. and Pommerening-Roser, A.: Distribution and ecophysiology of the nitrifying bacteria emphasizing cultured species, FEMS Microbiol. Ecol., 37(1), 1-9, 2001.

Lewis, E. and Wallace, D. W. R.: Program Developed for $\mathrm{CO}_{2}$ System Calculations, ORNL/CDLAC-105 Carbon Dioxide Information Analysis Center, Oak Ridge National Laboratory, US Department of Energy, Oak Ridge, Tennessee, 1998.

Lin, Z. Q., Zheng, J. L., Xu, M. C., Chen, J. S., and Zhu, J. H.: Nutrients in the Zhujiang from Gangzhou to Humen, Tropical Oceanol., 4(2), 52-58, 1985 (in Chinese).

Lipschultz, F., Wofsy, S. C., and Fox, L. E.: Nitrogen-metabolism of the eutrophic Delaware River ecosystem, Limnol. Oceanogr., 31(4), 701-716, 1986.

Lomas, M. W. and Lipschultz, F.: Forming the primary nitrite maximum: Nitrifiers or phytoplankton?, Limnol. Oceanogr., 51(5), 2453-2467, 2006.

Lyssenko, C. and Wheaton, F.: Impact of positive ramp short-term operating disturbances on ammonia removal by trickling and submerged-upflow biofilters for intensive recirculating aquaculture, Aquac. Eng., 35(1), 26-37, 2006.

Magalhaes, C. M., Joye, S. B., Moreira, R. M., Wiebe, W. J., and Bordalo, A. A.: Effect of salinity and inorganic nitrogen concentrations on nitrification and denitrification rates in intertidal sediments and rocky biofilms of the Douro River Estuary, Portugal, Water Res., 39(9), 1783-1794, 2005.

Malhautier, L., Degrange, V., Guay, R., Degorce-Dumas, J. R., Bardin, R., and Le Cloirec, P.: Estimating size and diversity of nitrifying communities in deodorizing filters using PCR and immunofluorescence, J. Appl. Microbiol., 85(2), 255-262, 1998.

Man, J. C. D.: Probability of most probable numbers, Eur. J. Appl. Microbiol., 1(1), 67-78, 1975.

Mao, Q. W., Shi, P., Yin, K. D., Gan, J. P., and Qi, Y. Q.: Tides and tidal currents in the Pearl River Estuary, Cont. Shelf Res., 24(16), 1797-1808, 2004.

National Research Council: Clean Coastal Water: Understanding and Reducing the Effects of Nutrient Pollution, National Academy Press, Washington, D.C., USA, 405, 2000.

Owens, N. J. P.: Estuarine nitrification - a naturally occurring fluidized-bed reaction, Estuar. Coast. Shelf Sci., 22(1), 31-44, 1986.

Pai, S. C., Tsau, Y. J., and Yang, T.: pH and buffering capacity problems involved in the determination of ammonia in saline water using the idophenol blue spectrophotometric method, Analyt. Chim. Acta, 434, 209-216, 2001.

Pakulski, J. D., Benner, R., Amon, R., Eadie, B., and Whitledge, T.: Community metabolism and nutrient cycling in the Mississippi River plume - evidence for intense nitrification at intermediate salinities, Mar. Ecol. Prog. Ser., 117(1-3), 207-218, 1995.

Pauer, J. J. and Auer, M. T.: Nitrification in the water column and sediment of a hypereutrophic lake and adjoining river system, Water Res., 34(4), 1247-1254, 2000.
PRWRC/PRRCC: The Pearl River Records (Zhujiang Zhi), Guangdong Sci. Technol. Press, Guangzhou, 104-142, 1991 (in Chinese).

Rabalais, N. N., Turner, R. E., and Wiseman, W. J.: Gulf of Mexico hypoxia, A.K.A. "The dead zone", Ann. Rev. Ecol. Syst., 33, 235-263, 2002.

Smith, V. H., Joye, S. B., and Howarth, R. W.: Eutrophication of freshwater and marine ecosystems, Limnol. Oceanogr., 51(1), 351-355, 2006.

Soetaert, K. and Herman, P. M. J.: Nitrogen dynamics in the Westerschelde Estuary (S.W Netherlands) estimated by means of the ecosystem model MOSES, Hydrobiologia, 311(1-3), 225-246, 1995.

Somville, M.: Use of nitrifying activity measurements for describing the effect of salinity on nitrification in the Scheldt Estuary, Appl. Environ. Microbiol., 47, 424-426, 1984.

Srna, R. F. and Baggaley, A.: Kinetic response of perturbed marine nitrification systems, J. Water Pollut., 47(3), 472-486, 1975.

Stehr, G., Bottcher, B., Dittberner, P., Rath, G., and Koops, H. P. The ammonia-oxidizing nitrifying population of the River Elbe Estuary, FEMS Microbiol. Ecol., 17(3), 177-186, 1995.

Strauss, E. A. and Lamberti, G. A.: Regulation of nitrification in aquatic sediments by organic carbon, Limnol. Oceanogr., 45(8), 1854-1859, 2000

Tang, Y. L.: The analysis and countermeasure of environmental problem in China, Zhongshan University Press, Guangzhou, pp. 14-17, 1997 (in Chinese).

Tian, X. P.: The distribution characteristics of temperature in Lingdingyang, Estuary of the Zhujiang, Tropical Oceanol., 13, 76-80, 1994 (in Chinese).

US EPA: Process design manual for nitrogen removal, EPA/625/R93/010, United States Environmental Protection Agency, Washington, D.C., 311, 1993.

Verity, P. G., Alber, M., and Bricker, S. B.: Development of hypoxia in well-mixed subtropical estuaries in the southeastern USA, Estuar. Coasts, 29(4), 665-673, 2006.

Wang, X. W., Wen, W. Y., and Liu, C. M.: Study on distributions of chemical species of nitrogen in summer in the Pearl River estuary and its adjacent sea areas, Mar. Sci., 27, 49-53, 2003 (in Chinese).

Wild, H. E., Sawyer, C. N., and McMahon, T. C.: Factors affecting nitrification kinetics, J. Water Pollut. Control Fed., 43(9), 18451854, 1971.

Wong, M. H. and Cheung, K. C.: Pearl River Estuary and Mirs Bay, South China, in: Estuarine systems of the South China Sea region: carbon, nitrogen and phosphorus fluxes, edited by: Smith, S. V., Dupra, V., Marshall Crossland, J. I., Crossland, C. J., LOICZ Reports \& Studies, vol. 14, pp. 7-16, LOICZ IPO, Texel, Netherlands, 2000.

Wu, J. X. and Shen, H. T.: Estuarine bottom sediment transport based on the "McLaren Model": A case study of Huangmaohai Estuary, South China, Estuar. Coast. Shelf Sci., 49, 265-279, 1999.

Xia, X. H., Yang, Z. F., Huang, G. H., Zhang, X. Q., Yu, H., and Rong, X.: Nitrification in natural waters with high suspendedsolid content - A study for the Yellow River, Chemosphere, 57(8), 1017-1029, 2004.

Xu, J., Wang, Y., Wang, Q., and Yin, J.: Nitrous oxide concentration and nitrification and denitrification in Zhujiang River Estuary, 
China, Acta Oceanol. Sin., 24(3), 122-130, 2005.

Yang, G. X. and Zhang, Z. X.: The analysis of chemical factor in the Pearl River Lingdingyang Estuary, Environ. Exploitation, 14(1), 31-40, 1999 (in Chinese).

Yin, K. D.: Monsoonal influence on seasonal variations in nutrients and phytoplankton biomass in coastal waters of Hong Kong in the vicinity of the Pearl River Estuary, Mar. Ecol. Prog. Ser., 245, 111-122, 2002.

Yin, K. D., Qian, P. Y., Wu, M. C. S., Chen, J. C., Huang, L. M., Song, X. Y., and Jian, W. J.: Shift from P to N limitation of phytoplankton growth across the Pearl River estuarine plume during summer, Mar. Ecol. Prog. Ser., 221, 17-28, 2001.
Zhai, W. D., Dai, M. H., Cai, W. J., Wang, Y. C., and Wang, Z. H.: High partial pressure of $\mathrm{CO}_{2}$ and its maintaining mechanism in a subtropical estuary: the Pearl River Estuary, China, Mar. Chem., 93(1), 21-32, 2005.

Zhang, J., Yu, Z. G., Wang, J. T., Ren, J. L., Chen, H. T., Xiong, H., Dong, L. X., and Xu, W. Y.: The subtropical Zhujiang (Pearl River) Estuary: Nutrient, trace species and their relationship to photosynthesis, Estuar. Coast. Shelf Sci., 49(3), 385-400, 1999.

Zhao, H. T.: Evolution of the Pearl River Estuary. China Ocean Press, Beijing, 356 pp, 1990 (in Chinese). 